\title{
Photodegradation of secondary organic aerosol generated from limonene oxidation by ozone studied with chemical ionization mass
} spectrometry

\author{
X. Pan ${ }^{1}$, J. S. Underwood ${ }^{1, *}$, J.-H. Xing ${ }^{1, * *}$, S. A. Mang, ${ }^{1, * *}$, and S. A. Nizkorodov ${ }^{1}$ \\ ${ }^{1}$ Department of Chemistry, University of California, Irvine, Irvine, California 92697-2025, USA \\ * currently at: Department of Chemistry, Loyola University, New Orleans, LA 70118, USA \\ *** currently at: Kyoto University Pioneering Research Unit for Next Generation, Kyoto University, \\ Gokasho, Uji, Kyoto, 611-0011 Japan \\ *** currently at: Department of Chemistry and Biochemistry, University of Maryland, Baltimore County, \\ Baltimore, MD 21250, USA
}

Received: 7 January 2009 - Published in Atmos. Chem. Phys. Discuss.: 24 February 2009

Revised: 18 May 2009 - Accepted: 25 May 2009 - Published: 15 June 2009

\begin{abstract}
Photodegradation of secondary organic aerosol (SOA) prepared by ozone-initiated oxidation of D-limonene is studied with an action spectroscopy approach, which relies on detection of volatile photoproducts with chemical ionization mass-spectrometry as a function of the UV irradiation wavelength. Efficient photodegradation is observed for a broad range of ozone $(0.1-300 \mathrm{ppm})$ and D-limonene (0.02$3 \mathrm{ppm}$ ) concentrations used in the preparation of SOA. The observed photoproducts are dominated by oxygenated C1C3 compounds such as methanol, formic acid, acetaldehyde, acetic acid, and acetone. The irradiation wavelength dependence of the combined yield of the photoproducts closely tracks the absorption spectrum of the SOA material suggesting that photodegradation is not limited to the UV wavelengths. Kinetic simulations suggest that $\mathrm{RO}_{2}+\mathrm{HO}_{2} / \mathrm{RO}_{2}$ reactions represent the dominant route to photochemically active carbonyl and peroxide species in the limonene SOA prepared in these experiments. Similar photodegradation processes are likely to occur in realistic SOA produced by $\mathrm{OH}-$ or $\mathrm{O}_{3}$-initiated oxidation of biogenic volatile organic compounds in clean air.
\end{abstract}

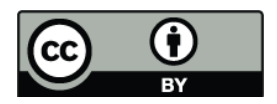

Correspondence to: S. A. Nizkorodov (nizkorod@uci.edu)

\section{Introduction}

Vegetation around the globe emits some $1150 \mathrm{Tg}$ /year of carbon in the form of volatile organic compounds (VOC) (Guenther et al., 1995). The terpene family, which includes isoprene $\left(\mathrm{C}_{5} \mathrm{H}_{8}\right)$, monoterpenes $\left(\mathrm{C}_{10} \mathrm{H}_{16}\right)$, and sesquiterpenes $\left(\mathrm{C}_{15} \mathrm{H}_{24}\right)$, accounts for over $50 \%$ of biogenic VOC emissions (Guenther et al., 2006). Atmospheric oxidation of terpenes by $\mathrm{OH}, \mathrm{O}_{3}$, and $\mathrm{NO}_{3}$ readily produces oxygenated terpenoids, which are generally less volatile than their precursors, and can therefore condense into secondary organic aerosol (SOA). At night time, terpenes are primarily oxidized by reactions with $\mathrm{NO}_{3}$ (Winer et al., 1984; Hallquist et al., 1999; Atkinson and Arey, 2003a; Spittler et al., 2006). Oxidation by $\mathrm{OH}$ and $\mathrm{O}_{3}$ dominates during daylight hours, when terpene emission rates are the highest (Atkinson and Arey, 2003a). Cl-atom initiated oxidation of monoterpenes may also contribute to SOA production in special cases (Cai and Griffin, 2006).

Limonene is one of the most abundant monoterpenes in the atmosphere (Geron et al., 2000; Roberts et al., 1985). Biogenic sources produce only R-enantiomer of limonene or D-limonene (CAS 5989-27-5); we are going to refer to it as simply "limonene" in this paper. Limonene is frequently observed in indoor environments because it is intentionally added to various cleaning products (Singer et al., 2006; Nazaroff and Weschler, 2004). Ozone initiated oxidation is the most important loss mechanism for limonene both outdoors and indoors. Therefore, gas-phase ozonolysis

Published by Copernicus Publications on behalf of the European Geosciences Union. 
Table 1. Typical conditions used for SOA preparation and collection. Note that ozone is always in excess relative to limonene (L).

\begin{tabular}{llll}
\hline Case & High & Intermediate & Low \\
\hline Initial ozone mixing ratio $(\mathrm{ppm})$ & 300 & 1.0 & 0.10 \\
Reactant added & $\mathrm{L}$ & $\mathrm{L}$ & $1: 19$ L:cyclohexane \\
Volume added $(\mu \mathrm{L})$ & 5 & 1 & 2 \\
Chamber volume $(\mathrm{L})$ & 220 & 360 & 360 \\
Initial limonene mixing ratio $(\mathrm{ppm})$ & 3.4 & 0.41 & 0.021 \\
Particles collected for (min)* & 3 & 10 & 30 \\
Flow through the filter (SLM) & 2 & 1.5 & 2 \\
\hline
\end{tabular}

* In all cases, particle collection commenced 30 min after the addition of the organic reactant.

of limonene has been studied extensively to characterize the chemical composition of condensable and volatile products (Hewitt and Kok, 1991; Grosjean et al., 1993; Hakola et al., 1994; Glasius et al., 2000; Koch et al., 2000; Feltham et al., 2000; Leungsakul et al., 2005a; Norgaard et al., 2006; Heaton et al., 2007; Iinuma et al., 2007; Walser et al., 2008), determine the yield of limonene SOA (Hoffmann et al., 1997; Weschler and Shields, 1999; Griffin et al., 1999; Wainman et al., 2000; Bonn et al., 2002; Rohr et al., 2003; Jonsson et al., 2006; Ng et al., 2006; Zhang et al., 2006), characterize the hygroscopic properties of organic particles in limonene SOA (Virkkula et al., 1999; Hartz et al., 2005; van Reken et al., 2005), and evaluate health effects of limonene oxidation products (Karlberg et al., 1992; Wolkoff et al., 2000; Wilkins et al., 2003; Kleno and Wolkoff, 2004; Nojgaard et al., 2005; Sunil et al., 2007; Wolkoff et al., 2008).

Terpene-derived SOA can remain in the atmosphere for 47 days before it is removed by deposition processes. During this time, the chemical composition of organic particles can be significantly modified because of their exposure to gas-phase oxidants, reactive and non-reactive uptake of semivolatile organic compounds, and various condensedphase photochemical processes initiated by sunlight (Guzman et al., 2006; Rudich et al., 2007; Robinson et al., 2007). For example, many terpene oxidation products, specifically aldehydes, ketones, and peroxides, are known to absorb radiation in the tropospheric actinic window $(\lambda>300 \mathrm{~nm})$ leading to photodegradation of SOA constituents on atmospherically relevant time scales (Walser et al., 2007; Mang et al., 2008). The solar photodegradation of SOA may potentially affect its optical, toxicological and hygroscopic properties. This study focuses on the mechanism of photochemical processes in SOA derived from oxidation of limonene by ozone, which will be referred to as "limonene SOA" for short.

Our group previously observed emission of multiple VOCs from limonene SOA exposed to UV radiation in the actinic region. We demonstrated that formaldehyde and formic acid are produced by photolysis of exocyclic secondary ozonides derived from limonene (Walser et al., 2007). The emission of $\mathrm{CO}, \mathrm{CH}_{4}$, small alkenes, alcohols, and car- bonyls was attributed to Norrish photocleavage of various carbonyls in limonene SOA (Mang et al., 2008). We measured the action spectra for the emission of $\mathrm{CO}$ and formic acid as a function of irradiation wavelength, and compared these spectra with the absorption spectrum of limonene SOA. Based on these observations, we concluded that carbonyl and peroxy functional groups in SOA are photodegraded on time scales that can be as short as several hours under realistic atmospheric conditions (Mang et al., 2008).

In this paper, we present a new instrument for characterization of photodegradation of SOA using chemical ionization mass spectrometry (CIMS). This instrument has considerably higher sensitivity to oxygenated VOCs compared to the infrared cavity ring-down instrument used in our previous works (Walser et al., 2007; Mang et al., 2008). The increased level of sensitivity makes it possible to study photodegradation of SOA prepared at more atmospherically relevant concentrations of terpene and ozone. Furthermore, action spectra can now be obtained simultaneously for all photodegradation products detectable by CIMS. We demonstrate the capabilities of this instrument using photodegradation of limonene SOA, which we previously studied with the cavity ring-down based instrument.

\section{Experimental}

\subsection{SOA sample preparation}

SOA was generated by a dark reaction between limonene vapor and ozone in zero-air at room temperature and ambient pressure. Home-made Teflon FEP bags with black covers were used as reaction chambers. They were filled to a desired volume (see Table 1) with dry air from Parker model 7552 FTIR purge gas generator. Ozone was generated from ultra-high purity (UHP) oxygen by a commercial ozone generator (Ozotech OZ2SS-SS-V/SW) and added to the chamber until a desired concentration was reached. A home-built ozone photometer continuously measured the ozone concentration in the chamber. The reaction was initiated by a microsyringe injection of a small volume of liquid limonene 
via a septum port in the chamber. Limonene quickly evaporated and reacted with ozone in the gas-phase. Limonene was purchased from Acros Organics (97\% stated purity) and used without additional purification.

In order to assess the effect of concentrations of limonene and ozone on the resulting SOA photochemistry, the initial concentrations were varied by three orders of magnitude. Typical conditions are presented in Table 1 for high $(\sim 300 \mathrm{ppm})$, intermediate $(\sim 1 \mathrm{ppm})$, and low $(\sim 0.1 \mathrm{ppm})$ initial ozone mixing ratios. To avoid cross-contamination, two separate chambers were used for low/intermediate and high concentration experiments. A scanning mobility particle sizer (SMPS) was used to monitor the particle formation in selected experiments.

Figure 1 shows a typical time dependence of ozone mixing ratio, average particle size, and particle mass and number concentrations in the reaction chamber for the intermediate concentration case. Following the injection of limonene, the ozone mixing ratio decreased $50 \%$ in 10 min resulting in a prompt particle growth. The particle concentration was approximately $8 \times 10^{5} \mathrm{~cm}^{-3}$ or $1000 \mu \mathrm{g} \mathrm{m}^{-3}$ and mean particle size was $\sim 120 \mathrm{~nm}$ after $10 \mathrm{~min}$ of reaction. After one hour, the number concentration decreased to $3 \times 10^{5} \mathrm{~cm}^{-3}$ while the mass concentration grew to almost $2500 \mu \mathrm{g} \mathrm{m}^{-3}$ and the mean size of particles increased to $\sim 220 \mathrm{~nm}$. This suggests that particles were not only coagulating but also gaining additional mass via continued oxidation of the first generation products (Ng et al., 2006) and/or by accretion of semivolatile species (Barsanti and Pankow, 2004, 2005, 2006; Kroll et al., 2007). Particle collection typically started 30 minutes after the addition of limonene.

SOA material was collected on six identical quartz-fiber filters using a home-built six-way filter holder and an oilfree pump (GAST 1023). Explicit SMPS measurements showed that particles were collected with better than $95 \%$ efficiency. The collection time and pump flow rate were $3 \mathrm{~min}$ and 2 SLM (standard liters per minute), $10 \mathrm{~min}$ and $1.5 \mathrm{SLM}$, and $30 \mathrm{~min}$ and $2 \mathrm{SLM}$ for ozone concentrations of $300 \mathrm{ppm}, 1 \mathrm{ppm}$, and $0.1 \mathrm{ppm}$, respectively. The weight of collected SOA material was measured with a Sartorius ME5F filter balance with $1 \mu \mathrm{g}$ readability and/or estimated from the SMPS data. Typically, each filter contained about 10, 30, and $50 \mu \mathrm{g}$ of SOA material for low, intermediate, and high concentration experiments, respectively. All filtered samples were placed under a flow of dry nitrogen for at least an hour in order to remove more volatile species that reversibly absorbed onto the filter surface and/or SOA material. The filters were used within $10 \mathrm{~h}$ of their preparation to avoid possible aging effects.

Particles were also collected by impaction on $2.5 \mathrm{~cm}$ diameter $\mathrm{CaF}_{2}$ windows in order to record UV/vis absorption spectra of SOA material with a Shimadzu UV-2450 dualbeam spectrophotometer. A relatively uniform film of SOA material was prepared by compressing the collected particles between two $\mathrm{CaF}_{2}$ windows and gently heating them.
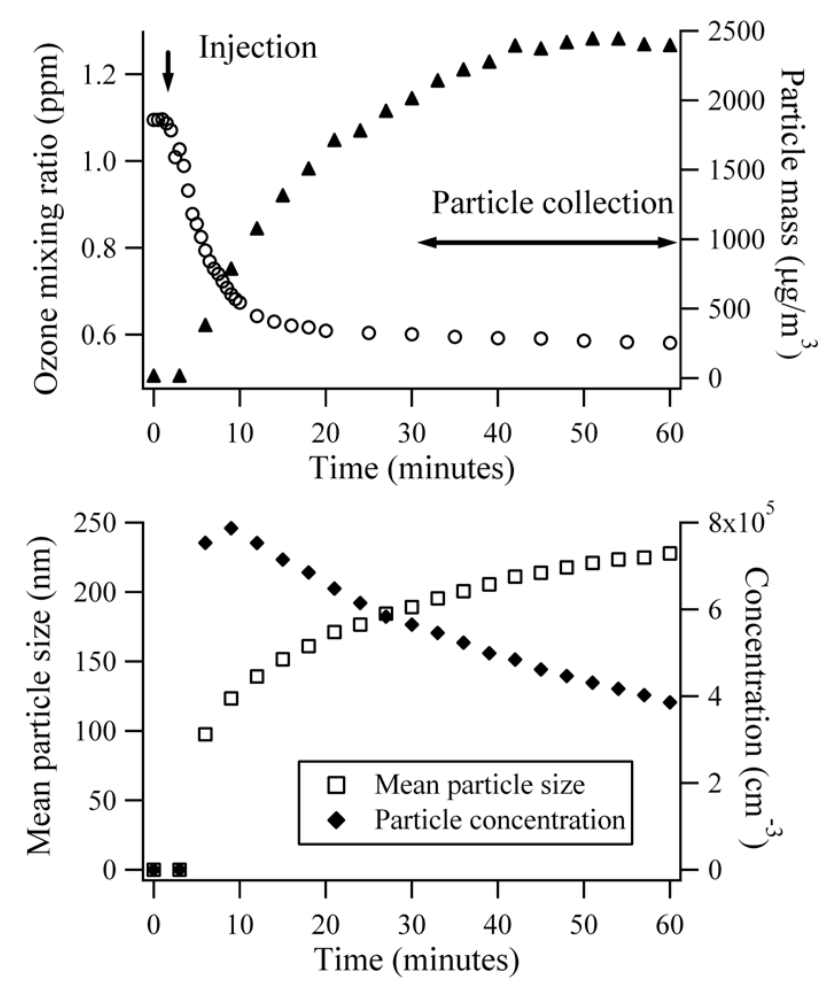

Fig. 1. The number (diamonds) and mass (triangles) concentrations of particles, and mixing ratio of ozone (circles) in the chamber during a typical SOA synthesis. The bottom panel also shows the average particle mobility equivalent diameter (squares).

Details of this procedure and representative absorption spectra of limonene SOA material were described by Mang et al. (2008).

\subsection{CIMS instrument}

Figure 2 shows a diagram of the experimental setup designed to measure the relative yields of gas-phase products formed in SOA photodegradation as a function of the irradiation wavelength. A filter loaded with SOA was placed inside a $14 \mathrm{~cm}^{3}$ glass flow cell equipped with a $2 \mathrm{~cm}$ quartz window. A combination of a $150 \mathrm{~W}$ Xe-lamp (Oriel) and a 1/8-m monochromator (Spectra-Physics) was used to generate a desired wavelength of radiation from $270 \mathrm{~nm}$ to $650 \mathrm{~nm}$. The slits of the monochromator were fully open resulting in $\sim 10 \mathrm{~nm}$ wavelength resolution (FWHM). A quartz lens was used to collimate the radiation on the filter. The radiation power was measured with a calibrated power monitor (Coherent PS19Q) and ranged from $0.050-0.45 \mathrm{~mW}$ and $0.40-2.6 \mathrm{~mW}$ in high and low/intermediate concentration experiments, respectively. For comparison, the flux of solar radiation at the Earth's surface at $30^{\circ}$ solar zenith angle between $300 \mathrm{~nm}$ and $310 \mathrm{~nm}$ is $\sim 4 \times 10^{14}$ photons $\mathrm{cm}^{-2} \mathrm{~s}^{-1}$ (Finlayson-Pitts and Pitts, 2000); this corresponds to about $0.3 \mathrm{~mW} \mathrm{~cm}^{-2}$. Therefore, the radiation flux to which the 


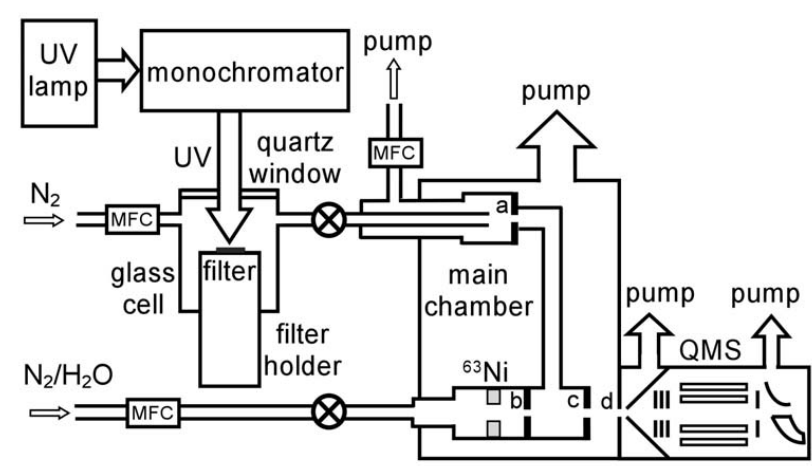

Fig. 2. Schematic diagram of the CIMS instrument constructed for this work. An SOA filter sample is irradiated with tunable $\mathrm{UV} / \mathrm{vis}$ radiation. Gaseous SOA photodegradation products are ionized by reactions with protonated water clusters produced in a ${ }^{63} \mathrm{Ni}$ source. Key: a, b, c, d=50, 100, 270, $500 \mu \mathrm{m}$ pinholes, respectively; $\mathrm{QMS}=$ quadrupole mass spectrometer; $\mathrm{MFC}=$ mass flow controller; $\otimes=$ shut-off valve.

SOA material was exposed to was representative of daytime atmospheric conditions.

Gas-phase products of photolysis were detected by a home-built CIMS apparatus shown in Fig. 2. UHP $\mathrm{N}_{2}$ flow passed over the irradiated filter sample and entered a $50 \mathrm{~cm}$ long, $0.06 \mathrm{~cm} \varnothing$ stainless steel tube, which was concentrically inserted into $0.40 \mathrm{~cm} \emptyset$ tube (symbol $\emptyset$ refers to the inner tube diameter). At the end of the outer tube, a small fraction of the flow exited through a $50 \mu \mathrm{m}$ pinhole (labeled "a" in Fig. 2), while the excess flow was pumped away through a mass flow controller. For high and intermediate concentration experiments $\left(\mathrm{O}_{3} \geq 1 \mathrm{ppm}\right)$, the sample flow and pump flow were set to $200 \mathrm{sccm}$ (standard cubic centimeters per minute) and $180 \mathrm{sccm}$, respectively, resulting in $\sim 0.05 \mathrm{~s}$ travel time from the SOA holder to pinhole "a". To increase the sensitivity in low concentration experiments ( $0.1 \mathrm{ppm}$ ozone), the sample and pump flows were reduced to 50 and $30 \mathrm{sccm}$, respectively, resulting in sample residence time of $0.2 \mathrm{~s}$. The pressure in the photolysis cell was kept at 700 Torr resulting in $\sim 20 \mathrm{sccm}$ flow through the pinhole.

The instrument was operated in a proton-transfer mode (Harrison, 1992), using protonated water clusters $\left(\mathrm{H}_{2} \mathrm{O}\right)_{n} \mathrm{H}^{+}$ as reagents. UHP $\mathrm{N}_{2}$ carried trace amounts of $\mathrm{H}_{2} \mathrm{O}$ vapor into a $1.0 \mathrm{~cm} \emptyset$ stainless steel tube terminated with a $100 \mu \mathrm{m}$ pinhole (labeled "b" in Fig. 2). The $\mathrm{N}_{2}$ flow was $20-40 \mathrm{sccm}$ and the pressure in the tube was typically in the range of 250-460 Torr. Protonated water clusters were generated by exposing the gas flow to $\beta$-particles emitted by a $15 \mathrm{mCi}{ }^{63} \mathrm{Ni}$ ring-source (Isotope Products Laboratories), which was mounted near the tube exit. The most abundant ions were $\left(\mathrm{H}_{2} \mathrm{O}\right)_{4} \mathrm{H}^{+}$and $\left(\mathrm{H}_{2} \mathrm{O}\right)_{3} \mathrm{H}^{+}$, with some $\left(\mathrm{H}_{2} \mathrm{O}\right)_{2} \mathrm{H}^{+}$ and $\left(\mathrm{H}_{2} \mathrm{O}\right)_{5} \mathrm{H}^{+}$also present. The free hydronium ion $\left(\mathrm{H}_{3} \mathrm{O}^{+}\right)$ peak was insignificant under normal operating conditions. The ions passed through the $100 \mu \mathrm{m}$ pinhole and entered the ionization volume, where the proton transfer reactions with analyte molecules took place.

The ion and sample flows were mixed together in a short cylindrical tube $(6 \mathrm{~cm}$ long; $1.0 \mathrm{~cm} \emptyset)$ equipped with a $270 \mu \mathrm{m}$ pinhole at the end (pinhole "c" in Fig. 2). Inside this ionization volume, protons transferred from water ions to analyte molecules with higher proton affinity (PA). The pressure in the tube was in the range of 40-80 Torr, and ion residence time was $\sim 0.4 \mathrm{~s}$. The resulting ions exited the pinhole into the main chamber of the CIMS instrument kept at 0.3-0.4 Torr by a mechanical pump/booster (Edwards Vacuum E2M80/EH500).

After traversing the main chamber for $2-5 \mathrm{~mm}$, ions entered the second differentially pumped chamber through a $500 \mu \mathrm{m}$ pinhole (labeled "d" in Fig. 2). The ions entered the third differentially pumped chamber, containing an ABB Extrel quadrupole mass spectrometer (QMS), through a $500 \mu \mathrm{m}$ conical skimmer. The skimmer, pinhole "c", and pinhole "d" were all concentrically aligned with respect to the entrance into an ABB Extrel axial molecular beam ionizer assembly mounted at the QMS entrance. The ionizing current was turned off, and the ion source was merely used to transmit the ions into the QMS. The QMS had four $19 \mathrm{~mm}$ diameter rods driven at $1.2 \mathrm{MHz}$ by a $300 \mathrm{~W}$ power supply. The ions were detected in single ion counting mode with a conversion dynode multiplier and pulse amplifier. The QMS and its electronics were controlled by a computer using Merlin Automation software.

\subsection{SOA photodegradation measurements}

The filters were first purged with a flow of dry nitrogen as described above. For each filter placed in the photolysis cell, several mass spectra were collected in the absence of irradiation in order to measure the background ion counts. After the irradiation was turned on, 15-45 additional mass spectra were collected. Each mass spectrum represented an average of 440 QMS microscans and took $2 \mathrm{~min}$ to acquire. The range was $10-400 \mathrm{~m} / \mathrm{z}$ in order to include monomeric and dimeric products of limonene oxidation and their possible volatile photodegradation products. The mass resolution was $\sim 1 \mathrm{~m} / z$.

A separate SOA filter was used for each irradiation wavelength. With six identical filter samples, photodegradation at six irradiation wavelengths could be examined for a given SOA batch. One of the irradiation wavelengths was always $270 \mathrm{~nm}$ for normalization purposes. In order to minimize possible aging effects due to slow reactions between SOA constituents, we finished photolysis of all collected samples as quickly as possible. It usually took $5-10 \mathrm{~h}$ to complete one set of filters, including purging the filters with dry nitrogen, loading the filters in the photolysis cell, recording the background mass spectra, irradiating the filters until the intensity of photoproduct peaks reached a stable level, and purging the system in preparation for the next filter sample. 


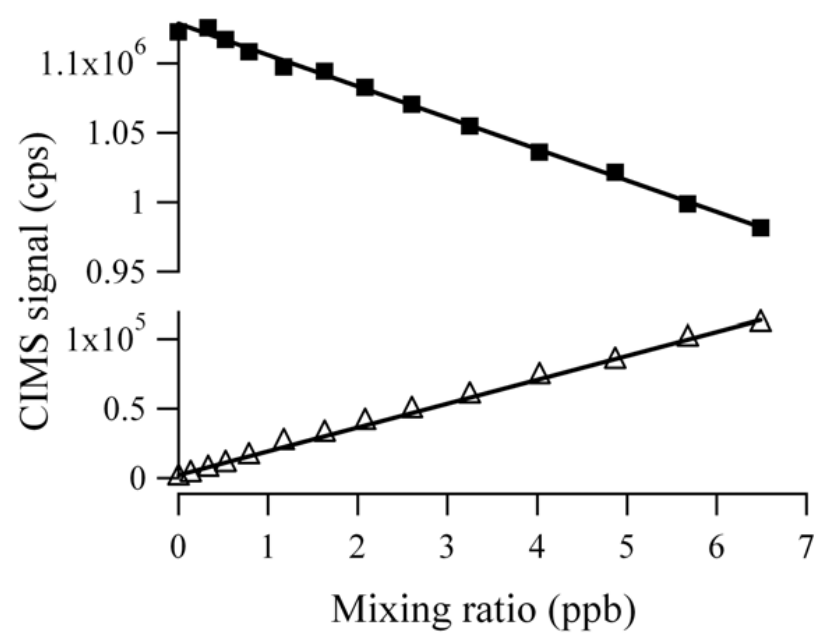

Fig. 3. Sample CIMS calibration using ${ }^{13} \mathrm{C}$-labeled acetone (Ac). Squares: sum of $\mathrm{H}^{+}\left(\mathrm{H}_{2} \mathrm{O}\right)_{n}$ ion counts. Triangles: sum of ion counts corresponding to $\mathrm{AcH}^{+}, \mathrm{AcH}^{+} \cdot \mathrm{H}_{2} \mathrm{O}, \mathrm{AcH}^{+} \cdot\left(\mathrm{H}_{2} \mathrm{O}\right)_{2}$, and $\mathrm{AcH}^{+} \cdot\left(\mathrm{H}_{2} \mathrm{O}\right)_{3}$. The estimated detection limit for $\mathrm{Ac}$ ( signal $=3 \sigma_{\text {noise }}$ ) is $0.01 \mathrm{ppb}$.

\section{Results}

\subsection{Calibration of the CIMS instrument}

The linearity of CIMS response was verified using acetone, one of the known SOA photodegradation products (Mang et al., 2008). The reference sample flow was prepared by combining 2-100 sccm of pre-mixed $1.11 \mathrm{ppm}{ }^{13} \mathrm{C}$-acetone in $\mathrm{N}_{2}$ with 20 SLM of UHP $\mathrm{N}_{2}$ using calibrated mass flow controllers. The resulting acetone mixing ratio ranged from 0 to $6.5 \mathrm{ppb}$. A trace of dimethyl sulfide impurity was present in the calibration mixture but it did not interfere with the acetone peaks. Figure 3 shows a calibration plot for the sum of major ions derived from ${ }^{13} \mathrm{C}$-acetone, specifically $\mathrm{AcH}^{+}$, $\mathrm{AcH}^{+} \cdot \mathrm{H}_{2} \mathrm{O}$ and $\mathrm{AcH}^{+} \cdot\left(\mathrm{H}_{2} \mathrm{O}\right)_{2}$, and $\mathrm{AcH}^{+} \cdot\left(\mathrm{H}_{2} \mathrm{O}\right)_{3}$. (A peak corresponding to $\mathrm{Ac}_{2} \mathrm{H}^{+}$was also found in spectra. However, it was significant only at concentrations well in excess of those used in Fig. 3.) The signal increases linearly for acetone mixing ratio below $6.5 \mathrm{ppb}$. The detection limit for acetone corresponds to $\sim 0.010 \mathrm{ppb}$ (mixing ratio at which the observed signal is equal to 3 times the root mean square deviation for the background noise). This value is typical for proton-transfer CIMS instruments (Lindinger et al., 1998).

In the presence of acetone or other ionizable VOCs in the sample flow, the intensities of all protonated water cluster ions $\left(\mathrm{H}_{2} \mathrm{O}\right)_{n} \mathrm{H}^{+}$decreased slightly. Within the uncertainty of the measurements, the decrease in the combined $\left(\mathrm{H}_{2} \mathrm{O}\right)_{n} \mathrm{H}^{+}$ count was exactly balanced by the increase in the total product ion count. The slopes for the increase in the acetone ion signal and decrease in the water cluster signal in Fig. 3 are slightly different because of the dimethyl sulfide impurity present in acetone; the sum of the dimethyl sulfide and acetone peaks have the same slope as that of water peaks. Even in experiments where the combined $\left(\mathrm{H}_{2} \mathrm{O}\right)_{n} \mathrm{H}^{+}$signal decreased by as much as $40 \%$, the overall ion signal was constant. The constant total ion count implied a relatively uniform QMS detection efficiency over the working $\mathrm{m} / \mathrm{z}$, range of this instrument.

The absolute intensities of the product peaks measured by this CIMS instrument depended in a complicated way on the selection of gas flows through the different mass flow controllers shown in Fig. 2. Therefore, additional calibration experiments were performed with a goal of achieving linearity over the broadest possible range of analyte concentrations. It was possible to achieve acceptable linearity for acetone concentrations up to $30 \mathrm{ppb}$ despite the fact that this concentration depleted the total $\left(\mathrm{H}_{2} \mathrm{O}\right)_{n} \mathrm{H}^{+}$signal by almost $30 \%$. To avoid possible saturation effects, the depletion of $\left(\mathrm{H}_{2} \mathrm{O}\right)_{n} \mathrm{H}^{+}$ was always kept well below $30 \%$ during all SOA photodegradation measurements described below.

\subsection{CIMS spectra of SOA photodegradation products}

Optical extinction coefficients of SOA constituents generally decrease with wavelength in the near UV range (Mang et al., 2008), whereas the intensity of Xe-lamp emission increases with wavelength. As a result of these two competing effects, there was an optimal irradiation wavelength ( $\sim 290 \mathrm{~nm}$ ), which produced the largest amount of volatile SOA photodegradation products. Figure 4 shows selected mass spectra observed before and during the $290 \mathrm{~nm}$ irradiation of SOA filters from low, intermediate, and high ozone concentration experiments.

In the absence of radiation, the observed mass spectrum typically contained only peaks at 55,73 , and $91 \mathrm{~m} / \mathrm{z}$ attributable to ion clusters $\left(\mathrm{H}_{2} \mathrm{O}\right)_{n} \mathrm{H}^{+}$, with $n=2,3$, and 4 , respectively. If the SOA filters were not sufficiently purged with dry nitrogen prior to their placement in the photolysis cell, additional ions were often observed in the background spectrum. In that case, purging continued until only $\left(\mathrm{H}_{2} \mathrm{O}\right)_{n} \mathrm{H}^{+}$ions remained. Irradiation of the filter resulted in the appearance of many additional peaks in the spectrum from photodegradation of SOA material. We explicitly verified that the observed VOCs were produced photochemically, and not as a result of a radiative heating of the sample (irradiation increased the filter temperature by less than $2^{\circ} \mathrm{C}$ ). Intentional heating of the sample to $\sim 100^{\circ} \mathrm{C}$ produced a completely different pattern of peaks in the mass spectrum (Fig. 5) that was very similar to the CIMS mass spectra of vaporized limonene SOA particles reported by Hearn and Smith (2006).

The expected photodegradation products should contain only $\mathrm{C}, \mathrm{H}$ and $\mathrm{O}$ atoms. The CIMS instrument is the most sensitive to oxygenated species, i.e., alcohols, carbonyls, carboxylic acids, and organic peroxides. The mass spectra in Fig. 4 contain families of peaks separated by $18 \mathrm{~m} / \mathrm{z}$ suggesting that each neutral product $\mathrm{M}$ produced several 
(a)
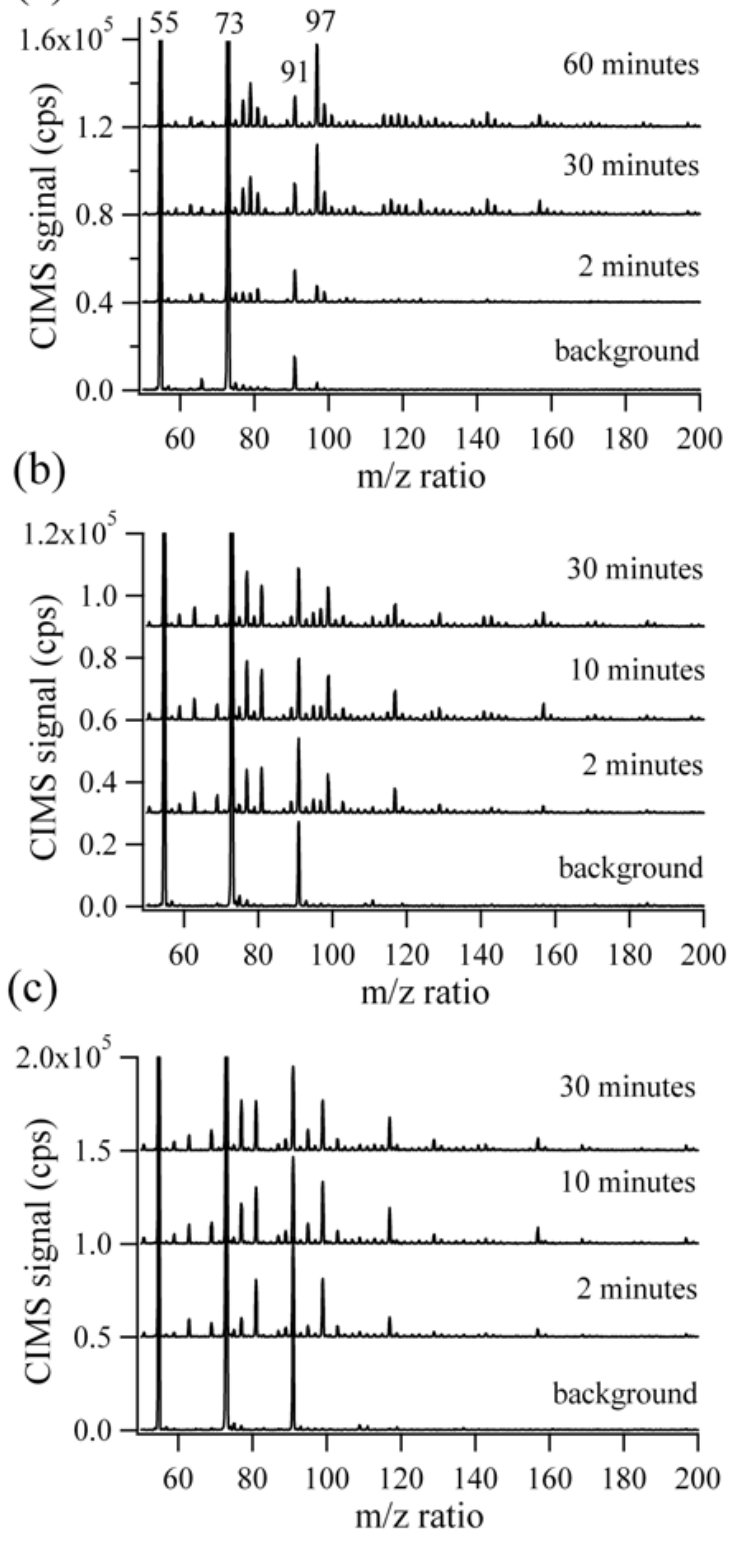

Fig. 4. Representative CIMS spectra of limonene photodegradation products observed after exposure of SOA samples to $290 \mathrm{~nm}$ radiation for the specified periods of time. Background spectra were taken immediately before the exposure. Data are presented for SOA prepared with (a) $300 \mathrm{ppm} \mathrm{O}_{3}$; (b) $1 \mathrm{ppm} \mathrm{O}_{3}$; (c) $100 \mathrm{ppb} \mathrm{O}_{3}$ under the conditions specified in Table 1. The spectra are offset for clarity.

ions $\mathrm{MH}^{+} \cdot\left(\mathrm{H}_{2} \mathrm{O}\right)_{n}$ with a range of $n$ values. Dimeric ions $\mathrm{M}_{2} \mathrm{H}^{+} \cdot\left(\mathrm{H}_{2} \mathrm{O}\right)_{n}$ were also detectable in the mass spectrum. Most peaks below $120 \mathrm{~m} / \mathrm{z}$ could be assigned (Table 2) to $\mathrm{CH}_{3} \mathrm{OH}, \mathrm{HC}(\mathrm{O}) \mathrm{OH}, \mathrm{CH}_{3} \mathrm{C}(\mathrm{O}) \mathrm{H}, \mathrm{CH}_{3} \mathrm{C}(\mathrm{O}) \mathrm{OH}$ and a $\mathrm{C} 3-$ carbonyl $\left(\mathrm{CH}_{3} \mathrm{C}(\mathrm{O}) \mathrm{CH}_{3}\right.$ or $\left.\mathrm{CH}_{3} \mathrm{CH}_{2} \mathrm{C}(\mathrm{O}) \mathrm{H}\right)$. Peaks at higher $\mathrm{m} / \mathrm{z}$ values, e.g., $141,143,157,169$, and $197 \mathrm{~m} / \mathrm{z}$ could not be assigned with certainty.

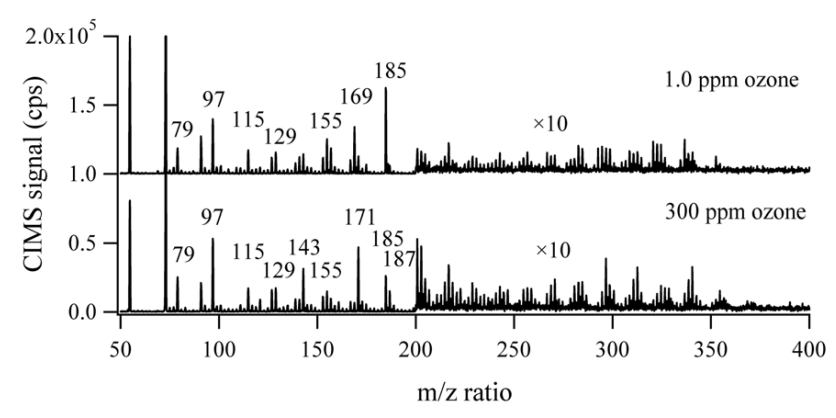

Fig. 5. Thermal desorption - CIMS spectra of SOA prepared under intermediate $(1.0 \mathrm{ppm})$ and high $(300 \mathrm{ppm})$ ozone concentrations.

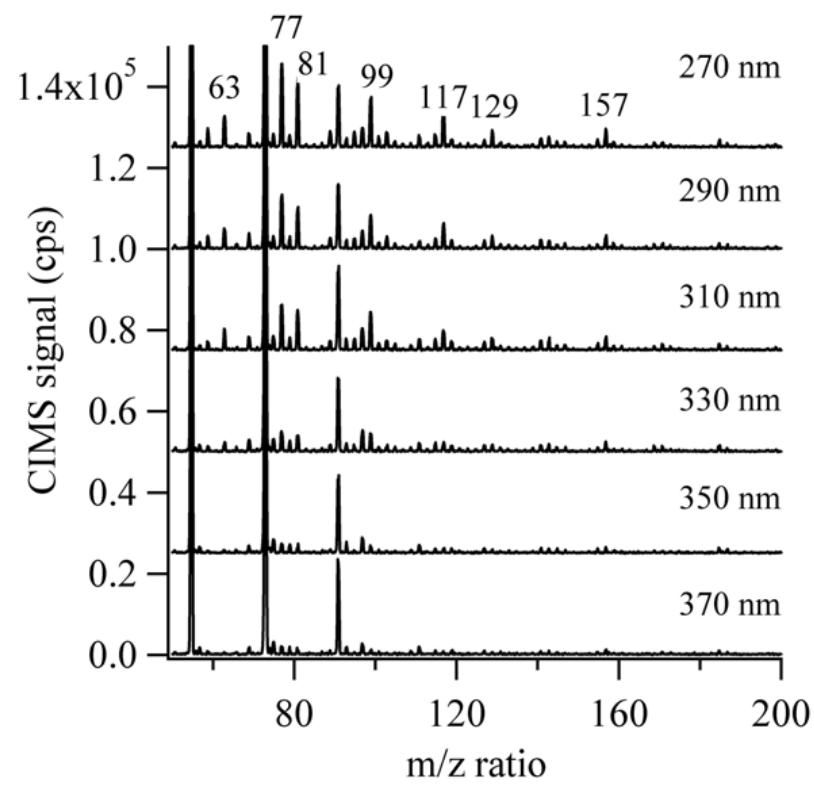

Fig. 6. Representative CIMS spectra of limonene photodegradation products at several selected irradiation wavelengths. All spectra were taken after 30 min of irradiation. The spectra are offset for clarity.

The mass spectra of photodegradation products for SOA produced at different ozone concentrations were somewhat different (Fig. 4). The high ozone concentration SOA had more unidentified peaks at higher $\mathrm{m} / \mathrm{z}$ values, and the observed products were more oxygenated. For example, the peaks attributable to $\mathrm{CH}_{3} \mathrm{C}(\mathrm{O}) \mathrm{OH}$ were enhanced relative to $\mathrm{CH}_{3} \mathrm{C}(\mathrm{O}) \mathrm{H}$ peaks in the high concentration experiments. The relative yield of the $\mathrm{C} 3$-carbonyl photoproduct was also enhanced at high $\mathrm{O}_{3}$. Finally, the high concentration SOA samples required less UV intensity to generate an observable signal, presumably because of the larger amount of SOA material collected on the filters. 
Table 2. Observed $\mathrm{m} / \mathrm{z}$ values and proposed assignments of major peaks in CIMS spectra of limonene SOA photodegradation products. $\mathrm{n} / \mathrm{o}=$ not observed. Major unidentified peaks included 141, 143, 157, 169, and $197 \mathrm{~m} / \mathrm{z}$. The last three columns list relative abundances of these products calculated under the assumption of equal CIMS sensitivity (mixing ratios of ozone used for SOA preparation are given in parenthesis).

\begin{tabular}{lrrrrrrrrrr}
\hline Photoproduct & $\mathrm{MH}^{+}$ & $\begin{array}{r}\mathrm{MH}^{+} \\
\mathrm{H}_{2} \mathrm{O}\end{array}$ & $\begin{array}{r}\mathrm{MH}^{+} . \\
\left(\mathrm{H}_{2} \mathrm{O}\right)_{2}\end{array}$ & $\begin{array}{r}\mathrm{MH}^{+} . \\
\left(\mathrm{H}_{2}\right)_{3}\end{array}$ & $\begin{array}{r}\mathrm{MH}^{+} . \\
\left(\mathrm{H}_{2} \mathrm{O}\right)_{4}\end{array}$ & $\mathrm{M}_{2} \mathrm{H}^{+}$ & $\begin{array}{r}\mathrm{M}_{2} \mathrm{H}^{+} \\
\mathrm{H}_{2} \mathrm{O}\end{array}$ & $\begin{array}{r}\text { Yield } \\
(0.1 \mathrm{ppm})\end{array}$ & $\begin{array}{r}\text { Yield } \\
(1 \mathrm{ppm})\end{array}$ & $\begin{array}{r}\text { Yield } \\
(300 \mathrm{ppm})\end{array}$ \\
\hline $\mathrm{CH}_{3} \mathrm{OH}$ & $\mathrm{n} / \mathrm{o}$ & 51 & 69 & 87 & 105 & $\mathrm{n} / \mathrm{o}$ & $\mathrm{n} / \mathrm{o}$ & $0.37-0.44$ & $0.30-0.35$ & $0.20-0.30$ \\
$\mathrm{HC}(\mathrm{O}) \mathrm{OH}$ & 47 & 65 & 83 & 101 & 119 & $\mathrm{n} / \mathrm{o}$ & $\mathrm{n} / \mathrm{o}$ & $0.024-0.067$ & $0.09-0.13$ & $0.36-0.7$ \\
$\mathrm{CH}_{3} \mathrm{C}(\mathrm{O}) \mathrm{H}$ & 45 & 63 & 81 & 99 & 117 & 89 & 107 & 1 & 1 & 1 \\
$\mathrm{CH}_{3} \mathrm{C}(\mathrm{O}) \mathrm{OH}$ & 61 & 79 & 97 & 115 & 133 & $\mathrm{n} / \mathrm{o}$ & $\mathrm{n} / \mathrm{o}$ & $0.027-0.05$ & $0.20-0.45$ & $2.2-3.8$ \\
$\mathrm{CH}_{3} \mathrm{C}(\mathrm{O}) \mathrm{CH}_{3}{ }^{*}$ & 59 & 77 & 95 & 113 & 131 & 117 & 135 & $0.40-0.51$ & $0.52-0.67$ & $0.41-0.51$ \\
\hline
\end{tabular}

* Could also be assigned to propanal, $\mathrm{CH}_{3} \mathrm{CH}_{2} \mathrm{C}(\mathrm{O}) \mathrm{H}$.

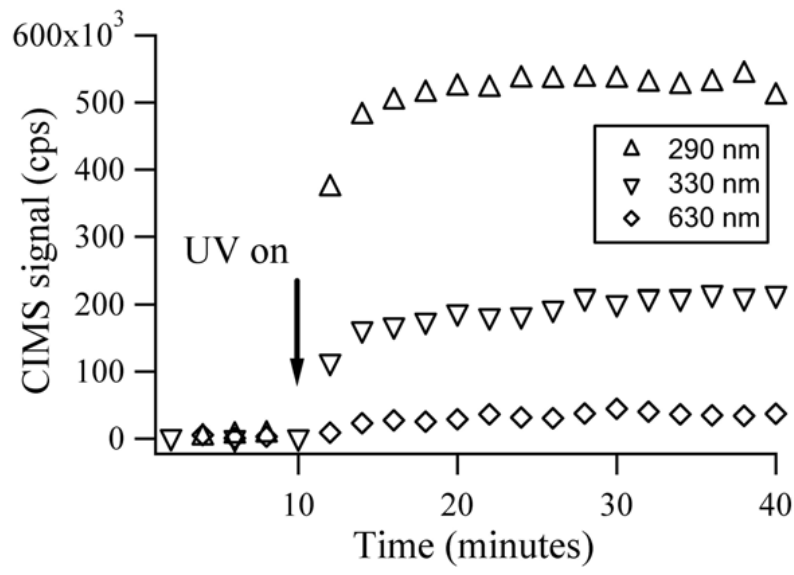

Fig. 7. Time dependence of the combined product ion signal between $50-400 \mathrm{~m} / \mathrm{z}$ at several irradiation wavelengths. A separate SOA filter was used for each wavelength. It took about 5-20 min for the signal to reach a steady state level after starting the irradiation. Constant background signal was subtracted to facilitate comparison of these time traces.

\subsection{Action spectra of SOA photodegradation products}

To investigate the wavelength dependence of the relative yields of SOA photodegradation products, mass spectra were recorded at different irradiation wavelengths for identical SOA samples. Figure 6 compares mass spectra observed after 30 min of irradiation at six different wavelengths for a $1 \mathrm{ppm}$ ozone experiment. For all irradiation wavelengths a similar distribution of the major product peaks was observed, although the overall intensities changed. This implies that there is no significant change in the photodegradation mechanisms over the studied wavelength range.

For each set of SOA filters, the experiments were conducted under conditions wherein the total ion current (TIC) was constant over the course of the measurements, and equal to the sum of all $\left(\mathrm{H}_{2} \mathrm{O}\right)_{n} \mathrm{H}^{+}$ion intensities prior to irradiation:

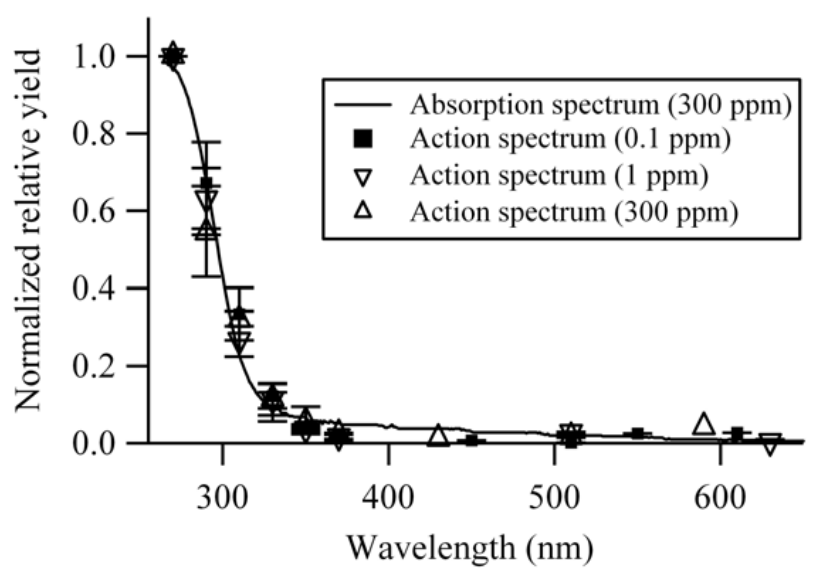

Fig. 8. Comparison between the absorption spectrum (solid line) and action spectra (symbols) of limonene SOA. The action spectra represent values of $Y_{\text {total }}^{\text {normalized }}(\lambda)$ defined in Eq. (5), measured by the CIMS instrument after $50 \mathrm{~min}$ of irradiation. Different symbols correspond to different initial ozone mixing ratios used in the SOA synthesis.

$\mathrm{TIC}=\left(\sum_{n}\left(\mathrm{H}_{2} \mathrm{O}\right)_{n} \mathrm{H}^{+}\right)_{\text {initial }}=$ constant

The total product ion current (PIC) was calculated by summing ion intensities from all detectable photodegradation products, or equivalently, by subtracting the $\left(\mathrm{H}_{2} \mathrm{O}\right)_{n} \mathrm{H}^{+}$ion intensities from the overall ion current.

$\mathrm{PIC}=\sum$ products $=\mathrm{TIC}-\left(\sum_{n}\left(\mathrm{H}_{2} \mathrm{O}\right)_{n} \mathrm{H}^{+}\right)$

We verified that both methods in Eq. (2) gave identical results within experimental uncertainties, although summing the products resulted in higher signal-to-noise ratios for TIC because of the low background ion signals in the absence of irradiation. 
Figure 7 shows a typical time dependence of PIC for SOA samples irradiated at three selected wavelengths. The signal increased from the baseline count to a higher value every time the UV radiation was turned on. The observed photoproducts did not appear instantaneously but instead reached a steady-state level on time scales of 5-20 min for samples prepared at different $\mathrm{O}_{3}$ concentrations. It took about the same time for PIC to drop back to the original level after the lights were turned off. This time was significantly longer than the time required for molecules to travel through the CIMS inlet lines $(<0.4 \mathrm{~s})$, and the residence time in the ionization region $(\sim 1 \mathrm{~s})$. The rate with which the signal reached a steady-state appeared to be limited by the desorption of the photodegradation products from the SOA material into the gas phase. Indeed, it took considerably longer for SOA samples prepared under high ozone concentration conditions to reach a steady-state because they had more SOA material deposited on the filters. In actual atmospheric particles, the time scale for the release of the photoproducts should be considerably faster, especially for non-sticky molecules, where this time is limited by the diffusion across the particle.

We constructed the action spectra by normalizing the observed peak intensities by the wavelength-dependent flux of photons incident on the filter.

$Y_{i}(\lambda)=\frac{\operatorname{Intensity}_{i}(\lambda)}{\lambda \times \operatorname{power}(\lambda) \times \mathrm{TIC}}$

$\operatorname{Intensity~}_{i}(\lambda)$ is the observed CIMS signal due to a given product for the specified irradiation wavelength, and $Y_{i}(\lambda)$ is the wavelength-dependent relative yield of this product. The wavelength appearing in the denominator is necessary to convert the measured radiation power (in watts) into the relative photon flux (photons per second). The total relative yield of photodegradation products was defined in a similar way:

$Y_{\text {total }}(\lambda)=\frac{\operatorname{PIC}(\lambda)}{\lambda \times \operatorname{power}(\lambda) \times \mathrm{TIC}}$

The yields defined in Eqs. (3) and (4) do not take into account the different sensitivities of the CIMS instrument to different VOCs. Therefore, in the absence of a more thorough calibration, the values of $Y_{i}$ cannot be used to directly compare absolute yields of different photodegradation products. However, they are still useful in comparing the yields for the same product at different irradiation wavelengths.

To facilitate comparison of experiments done on different sets of SOA samples, the yields were further normalized to the respective yield measured at $270 \mathrm{~nm}$, for example:

$Y_{\text {total }}^{\text {normalized }}(\lambda)=\frac{Y_{\text {total }}(\lambda)}{Y_{\text {total }}(270 \mathrm{~nm})}$

Figure 8 shows the resulting action spectrum for the normalized total product yield. The shape of the action spectrum appears to be remarkably insensitive to the initial ozone concentration. Furthermore, the photodegradation action spectra

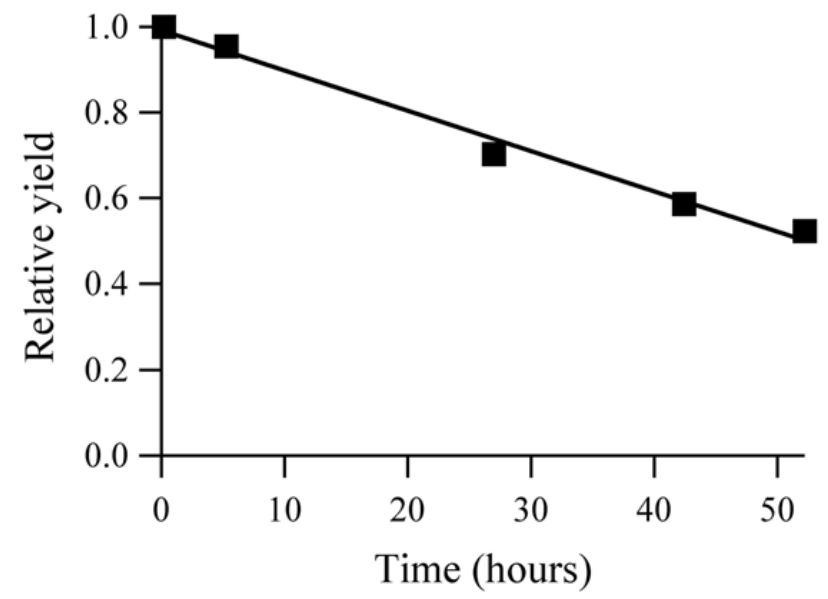

Fig. 9. Dependence of the total photodegradation product yield at $310 \mathrm{~nm}, Y_{\text {total }}(310 \mathrm{~nm})$, on the age of the limonene SOA sample. As the SOA material ages/volatilizes the relative product yield is reduced.

closely mimic the absorption spectrum of the SOA sample, which is also shown in the same plot.

\subsection{Effect of SOA evaporative loss on photodegradation}

In the process of conducting these measurements, we noticed that measured values of $Y_{\text {total }}$ were slowly decreasing with time as the filters were stored in darkness under dry nitrogen. One aging experiment was done to quantify the rate with which this reduction in photodegradation efficiency took place. High concentration limonene SOA particles were stored under $\mathrm{N}_{2}$ flow $(100 \mathrm{sccm})$ in darkness. At certain time intervals, one of the filters was retrieved from the storage environment, and its $Y_{\text {total }}$ was measured at $310 \mathrm{~nm}$. Figure 9 shows the resulting dependence of $Y_{\text {total }}(310 \mathrm{~nm})$ on storage time. The product signal decreased by $40 \%$ in about $50 \mathrm{~h}$.

This decrease was due to volatilization of organic material from the filter as confirmed by explicit measurements of mass loss in limonene SOA deposited on a quartz crystal microbalance. Freshly-prepared SOA samples emitted a number of low-molecular weight species at the beginning of purging. These compounds would not normally partition in the particle phase; they were reversibly adsorbed on the filter because of the elevated concentration of organic reactants in the chamber. After this initial loss of the most volatile species, the volatilization mass loss slowed down to about $1 \%$ per hour (Fig. 9). In order to avoid photolysis of volatile species, which is not representative of SOA photochemistry, but at the same time minimize the effect of slow volatilization, all measurements were done after one hour of purging and within $10 \mathrm{~h}$ of SOA generation $(<10 \%$ volatilization loss). 


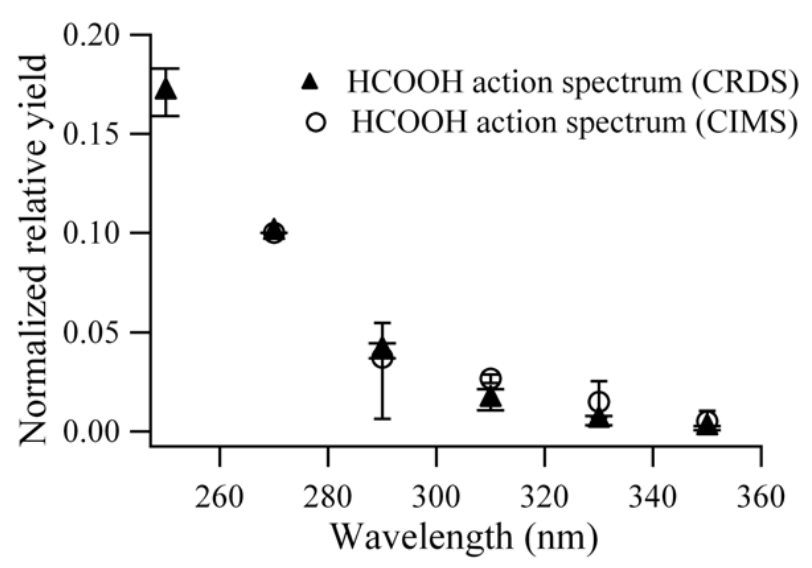

Fig. 10. Comparison of $\mathrm{HC}(\mathrm{O}) \mathrm{OH}$ action spectra recorded with the CIMS instrument and with the CRDS instrument for SOA prepared under high concentration conditions. Both spectra were normalized to $270 \mathrm{~nm}$ using Eq. (5).

\section{Discussion}

\subsection{Comparison of the CIMS and CRDS techniques}

Walser et al. (2007) and Mang et al. (2008) previously studied photodegradation of limonene SOA prepared under the conditions of ozone and limonene concentrations corresponding to the "high" case in Table 1. They used an infrared cavity ring-down spectroscopy (CRDS) instrument to detect volatile products of the photodegradation. The detection limit of the CRDS instrument is of the order of $10^{10} \mathrm{molec} / \mathrm{cm}^{3}$ for molecules with reasonably strong rotationally resolved bands in the mid-IR range (e.g., $\mathrm{CH}_{4}, \mathrm{CO}$, $\left.\mathrm{CH}_{2} \mathrm{O}, \mathrm{HC}(\mathrm{O}) \mathrm{OH}, \mathrm{CO}_{2}\right)$. With the typical CRDS operational pressure of 100 Torr, this translates into $3 \mathrm{ppb}$ effective detection limit for the mixing ratio. In contrast, the estimated detection limit for the new CIMS instrument is $0.01 \mathrm{ppb}$ (Fig. 3), which makes it possible to do experiments with considerably smaller quantities of SOA material. This work is the first report of photodegradation of limonene SOA prepared under more realistic atmospheric conditions (the "low" case in Table 1).

The CRDS and CIMS approaches provide complimentary information: CIMS works best for molecules with high proton affinities, whereas CRDS works best for small molecules with narrow IR absorption features. Because of this selectivity certain SOA photodegradation products can only be detected with one of these approaches. For example, Mang et al. (2008) reported an action spectrum for the release of $\mathrm{CO}$ resulting from Norrish type I splitting of carbonyls in the limonene SOA material. As the CIMS instrument is relatively insensitive to $\mathrm{CO}$, no direct comparison is possible in this case. Walser et al. (2007) reported an action spectrum for the release of formic acid during photolysis of limonene
SOA measured as a function of the irradiation wavelength. Formic acid is also one of the major products detected by the CIMS instrument. Figure 10 demonstrates that the action spectra for the formic acid release independently obtained by these two methods are in near perfect agreement.

\subsection{Effect of reactant concentrations on the action spectra}

Although there are some differences between the distributions of volatile SOA photodegradation products (Table 2), the wavelength dependence of the overall photodegradation rate appears to be remarkably insensitive to the concentrations of ozone and limonene used in SOA preparation. Figure 8 demonstrates that the action spectra observed under the conditions of high, intermediate, and low reactant concentrations are identical within the experimental uncertainties. Furthermore, all action spectra have the same shape as the absorption spectrum of a freshly-prepared limonene SOA material, which is also known to have insignificant dependence on the reactants' concentrations (Mang et al., 2008).

To understand the origins of the low degree of sensitivity of the photochemical properties of limonene SOA material to the concentrations of reactants, we have to consider the mechanism of oxidation of limonene by ozone. The first step in this process is concerted cycloaddition of ozone to the endocyclic double bond in limonene (Zhang et al., 2006; Donahue et al., 2007; Johnson and Marston, 2008). This splits the limonene's cyclohexene ring and produces two highly reactive Criegee Intermediates ( $\left.\mathrm{CI}^{*}\right)$, which can isomerize into stable products, for example limononic acid or 7-hydroxylimononaldehyde, decompose by expelling $\mathrm{OH}$ or $\mathrm{O}$-atom, or react with $\mathrm{H}$-donors such as alcohols or carboxylic acids to form organic peroxides (Fig. 11). Subsequent cross-reactions between alkylperoxy $\left(\mathrm{RO}_{2}\right)$ byproducts of the $\mathrm{CI}^{*}$ decomposition give rise a number of additional stable and free radical species:

$$
\begin{aligned}
& \mathrm{RO}_{2}+\mathrm{RO}_{2} \rightarrow \text { alcohol }+ \text { carbonyl }+\mathrm{O}_{2} \\
& \mathrm{RO}_{2}+\mathrm{RO}_{2} \rightarrow \mathrm{RO}+\mathrm{RO}+\mathrm{O}_{2} \\
& \mathrm{RO}_{2}+\mathrm{HO}_{2} \rightarrow \mathrm{ROOH}+\mathrm{O}_{2}
\end{aligned}
$$

Decomposition, isomerization, and $\mathrm{H}$-abstraction reactions involving alkoxy radicals (RO) lead to a "product explosion", with hundreds of chemically distinct species condensing in the limonene SOA matrix (Walser et al., 2008). To complicate the matters, the first generation products undergo further reactions after condensing in the particle phase (Kroll and Seinfeld, 2008).

Detailed kinetic modeling of this chemistry is challenging, but we can get some insight into the mechanism from the simplified kinetic model presented in Table 3. This model assumes that the majority of $\mathrm{CI}^{*}$ species undergo $\mathrm{OH}-\mathrm{loss}$ ( $\sim 60 \%$ ), with the resulting free radical being instantaneously 
Table 3. Simplified kinetic mechanism of limonene ozonolysis. L=limonene. Product groups P1, P2, P3, and P4 refer to stable products of $\mathrm{CI}^{*}$ isomerization, $\mathrm{RO}_{2}+\mathrm{RO}_{2}$ reactions, $\mathrm{RO}_{2}+\mathrm{HO}_{2}$ reactions, and reactions of Stabilized Criegee Intermediate (SCI) with $\mathrm{H}$-donors, respectively. Rate constant units are $\mathrm{s}^{-1}$ and $\mathrm{cm}^{3} \mathrm{molec}^{-1} \mathrm{~s}^{-1}$ for unimolecular and bimolecular reactions, respectively. For reactions with multiple product channels, the rate constants refer to the overall reaction. Rates and branching ratios are taken or estimated from Atkinson and Arey (2003b), Johnson and Marston (2008), Leungsakul et al. (2005b), Finlayson-Pitts and Pitts (2000), and Sander et al. (2006).

\begin{tabular}{|c|c|c|}
\hline Reaction & Rate constant & Yield \\
\hline 1a. $\mathrm{O}_{3}+\mathrm{L} \rightarrow \mathrm{CI}^{*}\left(+\mathrm{O}_{2}\right) \rightarrow \mathrm{RO}_{2}+\mathrm{OH}$ (decomposition) & $2 \times 10^{-16}$ & 0.6 \\
\hline 1b. $\mathrm{O}_{3}+\mathrm{L} \rightarrow \mathrm{CI}^{*} \rightarrow \mathrm{SCI}$ (collisional stabilization) & $2 \times 10^{-16}$ & 0.2 \\
\hline 1c. $\mathrm{O}_{3}+\mathrm{L} \rightarrow \mathrm{CI}^{*} \rightarrow \mathrm{P} 1$ (isomerization) & $2 \times 10^{-16}$ & 0.2 \\
\hline 2a. $\mathrm{RO}_{2}+\mathrm{RO}_{2} \rightarrow \mathrm{P} 2+\mathrm{P} 2+\mathrm{O}_{2}$ (stable products) & $1 \times 10^{-13}$ & 0.5 \\
\hline 2b. $\mathrm{RO}_{2}+\mathrm{RO}_{2} \rightarrow \mathrm{RO}+\mathrm{RO}+\mathrm{O}_{2}$ (alkoxy channel) & $1 \times 10^{-13}$ & 0.5 \\
\hline 3. $\mathrm{RO} \rightarrow$ isomerization $\left(+\mathrm{O}_{2}\right) \rightarrow \mathrm{RO}_{2}$ & $1 \times 10^{5}$ & \\
\hline 4. $\mathrm{RO}+\mathrm{O}_{2} \rightarrow \mathrm{P} 2+\mathrm{HO}_{2}$ & $8 \times 10^{-15}$ & \\
\hline 5. $\mathrm{OH}+\mathrm{L}, \mathrm{P} 1, \mathrm{P} 2, \mathrm{P} 3$ or $\mathrm{P} 4\left(+\mathrm{O}_{2}\right) \rightarrow \mathrm{RO}_{2}$ & $5 \times 10^{-11}$ & \\
\hline 6. $\mathrm{OH}+\mathrm{O}_{3} \rightarrow \mathrm{HO}_{2}+\mathrm{O}_{2}$ & $7.3 \times 10^{-14}$ & \\
\hline 7. $\mathrm{HO}_{2}+\mathrm{RO}_{2} \rightarrow \mathrm{P} 3$ & $1 \times 10^{-11}$ & \\
\hline 8. $\mathrm{SCI}+\mathrm{P} 1, \mathrm{P} 2$ or $\mathrm{P} 3 \rightarrow \mathrm{P} 4$ & $1 \times 10^{-14}$ & \\
\hline 9. $\mathrm{OH}+\mathrm{HO}_{2} \rightarrow \mathrm{H}_{2} \mathrm{O}+\mathrm{O}_{2}$ & $1.1 \times 10^{-10}$ & \\
\hline 10. $\mathrm{HO}_{2}+\mathrm{HO}_{2} \rightarrow \mathrm{H}_{2} \mathrm{O}_{2}+\mathrm{O}_{2}$ & $1.9 \times 10^{-12}$ & \\
\hline 11. $\mathrm{HO}_{2}+\mathrm{O}_{3} \rightarrow \mathrm{OH}+2 \mathrm{O}_{2}$ & $1.9 \times 10^{-15}$ & \\
\hline 12. $\mathrm{OH} \rightarrow$ wall loss & $1 \times 10^{-1}$ & \\
\hline 13. $\mathrm{HO}_{2}, \mathrm{RO}_{2}$ or $\mathrm{SCI} \rightarrow$ wall loss & $5 \times 10^{-3}$ & \\
\hline
\end{tabular}

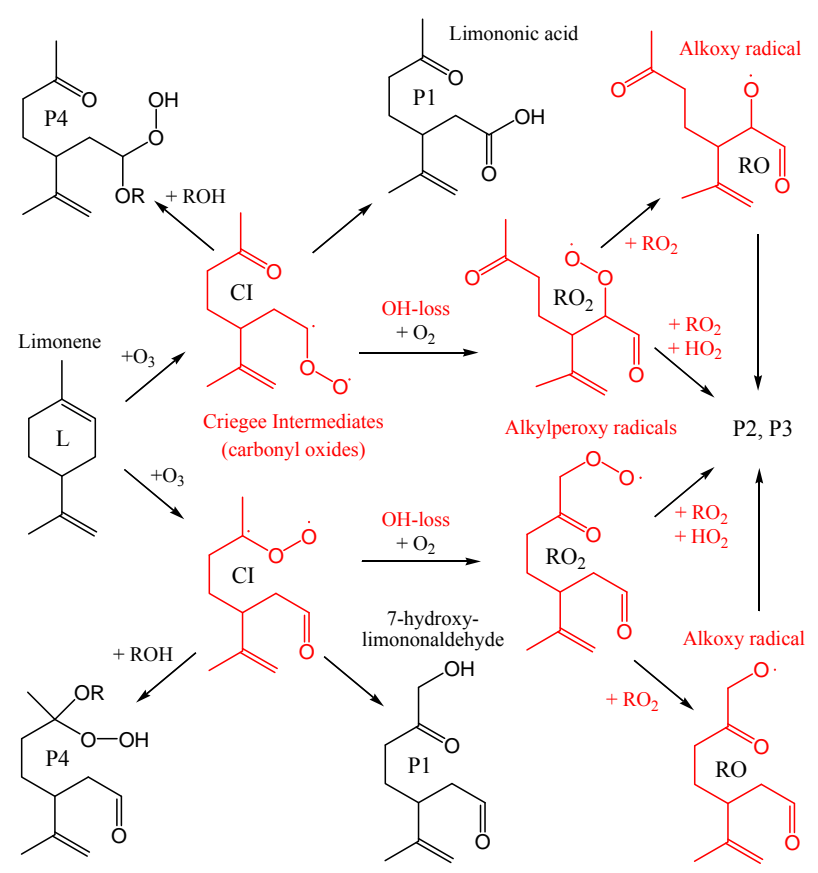

Fig. 11. Schematic diagram of initial chemical processes in limonene ozonolysis. Important free radical species are shown in red. Symbols inside the structures refer the abbreviations used in text and in Table 3. converted into an alkylperoxy species (Reaction 1a). A significant fraction $(\sim 20 \%)$ of $\mathrm{CI}^{*}$ is collisionally stabilized (Reaction $1 \mathrm{~b})$; the remaining $(\sim 20 \%) \mathrm{CI}^{*}$ isomerizes into first generation products grouped into category "P1" (Reaction 1c). These branching ratios are consistent with the commonly assumed yields of $\mathrm{OH}$ and stabilized Criegee Intermediate (SCI) in the ozonolysis of monoterpenes (Johnson and Marston, 2008; Leungsakul et al., 2005a). Similar to the approach of Leungsakul et al. (2005b) and Li et al. (2007), all $\mathrm{RO}_{2}$ species are lumped together in this model in order to make it tractable. The chosen rate constant and branching ratios for the $\mathrm{RO}_{2}$ cross-reactions ( $2 \mathrm{a}$ and $\mathrm{b}$ ) are appropriate for large secondary $\mathrm{RO}_{2}$ species with additional oxygen atoms in the chains attached to the -COO group (FinlaysonPitts and Pitts, 2000). The alcohols and carbonyls formed by the $\mathrm{RO}_{2}$ cross-reactions are grouped into product category "P2". The RO species, which are also lumped together, are assumed to be capable of efficient isomerization by $\mathrm{H}-$ shift, with subsequent $\mathrm{O}_{2}$ attachment regenerating $\mathrm{RO}_{2}(\mathrm{Re}-$ action 3). More detailed examples of these isomerization reactions can be found in the paper by Walser et al. (2008). Reaction (4) between $\mathrm{RO}$ and $\mathrm{O}_{2}$ offers a pathway to $\mathrm{HO}_{2}$ and generates additional products in the P2 category. Additional $\mathrm{RO}_{2}$ species can be generated from Reaction (5) of $\mathrm{OH}$ with limonene or with any of the stable products occurring with near gas-kinetic rates. $\mathrm{HO}_{2}$ can also be produced from Reaction (6) between $\mathrm{OH}$ and $\mathrm{O}_{3}$ (Nizkorodov et al., 2000). Reaction (7) between $\mathrm{RO}_{2}$ and $\mathrm{HO}_{2}$ radicals 
are known to be fast and they generally produce organic peroxides (Finlayson-Pitts and Pitts, 2000), which are lumped together under "P3" category. Finally, the SCI species are assumed to undergo a slow Reaction (8) with products P1-P3 forming alkoxyhydroperoxides (Fig. 11), which are lumped into product group "P4". Several termination $(9,10,12,13)$ and propagation (11) reactions are also included in the mechanism to prevent an unrealistic build-up of free radicals.

We can make approximate associations between the groups $\mathrm{P} 1-\mathrm{P} 4$ and actual chemical functional groups in the product molecules. P1-type products are likely to contain either two carbonyls or one carbonyl and one carboxyl functional group (see examples in Fig. 11). The first carbonyl functional group comes from the initial splitting of the endocyclic double bond, whereas the second functional group results from the unimolecular isomerization of CI*. P2-type products are likely to contain at least two carbonyls or one carbonyl and one hydroxyl functional groups because $\mathrm{RO}_{2}$ cross reactions are known to result in an alcohol/carbonyl pair (Finlayson-Pitts and Pitts, 2000). P3-type products are expected to be dominated by organic peroxides $\mathrm{ROOH}$. Alkoxyhydroperoxidic P4-type products have dimeric structures $\mathrm{R}_{1} \mathrm{R}_{1}^{\prime} \mathrm{C}(\mathrm{OOH}) \mathrm{OR}_{2}$ in a sense that they contain leftovers of two limonene molecules; efficient formation of such dimers have been observed by Heaton et al. (2007) and Tolocka et al. (2006) during early stages of $\alpha$-pinene ozonolysis. In addition to the -OO- peroxy group, both P3 and P4 should contain carbonyl function groups from the initial splitting of the endocyclic double bond.

Kinetic simulations of this simplified mechanism with the initial concentrations of ozone and limonene from Table 1 resulted in the product distribution shown in Fig. 12. Despite the fact that ozone and limonene concentrations change by 2-3 orders of magnitude in our experiments, the final distribution appears to be dominated by the $\mathrm{P} 2$ products from $\mathrm{RO}_{2}+\mathrm{RO}_{2}$ reactions in all cases. In the high and intermediate cases, the yield of $\mathrm{P} 2$ products is close to the initial yield of $\mathrm{OH}$ (and $\mathrm{RO}_{2}$ ) in the CI* decomposition. In the low case, the loss of $\mathrm{RO}_{2}, \mathrm{HO}_{2}$ and SCI by Reaction (13) starts to compete with formation of products $\mathrm{P} 2-\mathrm{P} 4$, and the yield of direct CI* isomerization products $\mathrm{P} 1$ increases. According to this model, only P1-type products should remain in the low concentration limit; all four types of products should be present in the high concentration limit.

We believe that our experimental conditions correspond to the high concentration regime, wherein the majority of products are generated via the $\mathrm{RO}_{2}$ cross-reactions (2). This assumption is supported by: (i) the strikingly large number of peaks in the high-resolution limonene SOA mass spectrum attributed to RO chemistry (Walser et al., 2008); (ii) the insensitivity of the high-resolution SOA mass spectrum to ozone concentration (Walser et al., 2008); (iii) the lack of dependence of the observed action spectra of limonene SOA material on the reactant concentrations. With the expected order of product yields $(\mathrm{P} 2>\mathrm{P} 1 \sim \mathrm{P} 3 \sim \mathrm{P} 4)$, the car-

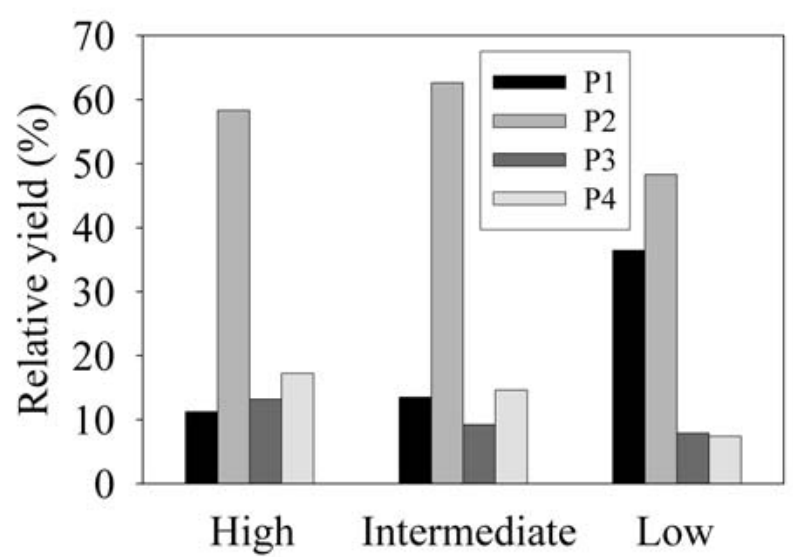

Fig. 12. Distribution of products $\mathrm{P} 1-\mathrm{P} 4$ resulting from kinetic simulations of mechanism in Table 3 using the initial ozone and limonene concentrations listed in Table 1.

bonyl group should be the most important functional group with photochemical activity in the actinic region of the solar spectrum. The fraction of oxygen sitting in the -OO- peroxy groups should also be significant. As discussed by Mang et al. (2008), the absorption spectrum of limonene SOA material in the vicinity of $300 \mathrm{~nm}$ can indeed be modeled as a composition of overlapping $n \rightarrow \pi^{*}$ bands of carbonyls and $n \rightarrow \sigma^{*}$ bands of peroxides.

\subsection{Effect of reactant concentrations on the photodegradation products}

The distribution of gaseous products of limonene SOA photodegradation does depend on the concentrations of reactants used in the SOA synthesis (Table 2). The degree of oxidation in the observed products appears to increase at higher ozone concentrations. For example, $\mathrm{CH}_{3} \mathrm{C}(\mathrm{O}) \mathrm{OH}$ and $\mathrm{CH}_{3} \mathrm{C}(\mathrm{O}) \mathrm{H}$ represent the most easily detectable photoproducts under the "high" and "low" conditions, respectively. This behavior can be linked to the chemistry of the less reactive exocyclic double bond in limonene. While it is likely to survive the initial attack by ozone, it may still be oxidized by the excess ozone after the first generation products $\mathrm{P} 1-\mathrm{P} 2$ condense in the aerosol phase (Ng et al., 2006). SOA prepared under low concentration conditions still contains a number of molecules with intact exocyclic double bounds (Leungsakul et al., 2005b; Walser et al., 2008). For example, peaks at $169 \mathrm{~m} / \mathrm{z}$ and $185 \mathrm{~m} / \mathrm{z}$ in the SOA thermal desorption mass spectrum (Fig. 5) likely correspond to protonated limononaldehyde and limononic acid, respectively, both of which still have this double bond. As the ozone concentration increases, the peaks at 169 and $185 \mathrm{~m} / \mathrm{z}$ become smaller, whereas peaks at 171 and $187 \mathrm{~m} / \mathrm{z}$ grow in as a result of the following reactions: 


$$
\begin{aligned}
& >\mathrm{C}=\mathrm{CH}_{2}+\mathrm{O}_{3} \rightarrow>\mathrm{C}=\mathrm{O}+\mathrm{CH}_{2} \mathrm{OO}(\Delta m / z=+2) \\
& \mathrm{CH}_{2} \mathrm{OO}+\mathrm{RC}(\mathrm{O}) \mathrm{OH} \rightarrow \mathrm{HOOCH}_{2} \mathrm{OC}(\mathrm{O}) \mathrm{R}
\end{aligned}
$$

The latter reaction corresponds to scavenging of the Criegee intermediate $\mathrm{CH}_{2} \mathrm{OO}$ by carboxylic acid groups within the SOA matrix (Gomez et al., 2006). The increase in the oxygen content of SOA caused by these and other oxidative processes is expected to increase on average the oxygen content in the SOA photodegradation products.

\subsection{Atmospheric relevance}

Several recent aerosol chamber studies underscored the importance of measuring SOA yields and characterizing SOA chemical composition at low loadings of organic material (Presto and Donahue, 2006; Shilling et al., 2008; Pathak et al., 2007) and with careful control of $\mathrm{NO}_{\mathrm{x}}$ levels (Donahue et al., 2005; Presto et al., 2005; Jaoui et al., 2006; Zhang et al., 2006; Yu et al., 2008). The lowest concentrations of reactants used in this study $(100 \mathrm{ppb}$ ozone; $20 \mathrm{ppb}$ limonene) are still higher than the typical atmospheric values. The SOA formation appears to be dominated by the $\mathrm{RO}_{2}+\mathrm{RO}_{2}$ and $\mathrm{RO}_{2}+\mathrm{HO}_{2}$ reactions under our conditions of low- $\mathrm{NO}_{\mathrm{x}}$ and high concentration of the organics. In a more realistic atmospheric environment, $\mathrm{RO}_{2}$ radicals will instead react with atmospheric $\mathrm{NO}$ when both $\left(k_{\mathrm{RO}_{2}+\mathrm{NO}} \times[\mathrm{NO}]\right) /\left(k_{\mathrm{RO}_{2}+\mathrm{HO}_{2}} \times\left[\mathrm{HO}_{2}\right]\right)$ and

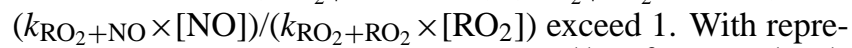
sentative rate constants, $k_{\mathrm{RO}_{2}+\mathrm{NO}} \sim 10^{-11} \mathrm{~cm}^{3}$ molec $^{-1} \mathrm{~s}^{-1}$, $k_{\mathrm{RO}_{2}+\mathrm{RO}_{2}} \sim 10^{-13} \mathrm{~cm}^{3}$ molec $^{-1} \mathrm{~s}^{-1}$,

$k_{\mathrm{RO}_{2}+\mathrm{HO}_{2}} \sim 10^{-11} \mathrm{~cm}^{3}$ molec $^{-1} \mathrm{~s}^{-1}$ (Atkinson and Arey, $2003 \mathrm{~b}$ ), and with typical peak concentrations in remote areas, $\quad\left[\mathrm{HO}_{2}+\mathrm{RO}_{2}\right]=10^{8}-10^{9}$ molec $\mathrm{cm}^{-3}, \quad[\mathrm{NO}]=10^{8}-$ $10^{10}$ molec cm $^{-3}$ (Finlayson-Pitts and Pitts, 2000), the involvement of NO can be ignored only under unusually clean atmospheric conditions. Furthermore, ozone is not the only oxidant responsible for oxidation of terpenes; $\mathrm{OH}$ and $\mathrm{NO}_{3}$ also make a significant contribution (Atkinson and Arey, 2003b). This brings up the following question: do the photodegradation processes observed in this study bear any relevance to the photochemical processes occurring in realistic organic aerosols?

We argue that the mechanism of photodegradation of SOA prepared in a $\mathrm{NO}_{\mathrm{x}}$-free environment will be similar to that for SOA prepared by oxidation of terpenes in the presence of NO. The $\mathrm{RO}_{2}+\mathrm{NO}$ reaction generates $\mathrm{RO}$ radical, which eventually becomes a carbonyl species that is similar or even identical to the carbonyls produced by the $\mathrm{RO}_{2}+\mathrm{RO}_{2}$ reactions. For the large $\mathrm{RO}_{2}$ species generated by monoterpene ozonolysis, the yield of organic nitrates $\mathrm{RONO}_{2}$ produced by the $\mathrm{RO}_{2}+\mathrm{NO}$ reaction can be substantial $(\sim 25 \%)$ but the $-\mathrm{ONO}_{2}$ group is characterized by low absorption cross sections at $\lambda>300 \mathrm{~nm}$, the actinic wavelengths capable of reaching the lower troposphere (Ungnade and Smiley, 1956;
Clemitshaw et al., 1997; Talukdar et al., 1997; Zhu and Kellis, 1997). The $\mathrm{OH}$-initiated oxidation of terpenes will give a different distribution of SOA constituents, with a considerably reduced fraction of peroxides amongst the final products compared to the ozone-initiated case. However, carbonyl products are expected to be just as important in photochemically produced SOA as in SOA derived from the ozone + olefin chemistry. We conclude that photodegradation processes taking place in our "idealized" limonene SOA material should be representative of realistic biogenic SOA as long as carbonyl functional groups remain the dominant absorbers in the actinic range of the tropospheric solar radiation.

Acknowledgements. Support for this work was provided by the National Science Foundation through the Environmental Molecular Science Institute program, grant CHE-0431312, and Atmospheric Chemistry program, grant ATM-0509248.

Edited by: C. George

\section{References}

Atkinson, R. and Arey, J.: Gas-phase tropospheric chemistry of biogenic volatile organic compounds: a review, Atmos. Environ., 37, S197-S219, 2003a.

Atkinson, R. and Arey, J.: Atmospheric degradation of volatile organic vcompounds, Chem. Rev., 103, 4605-4638, 2003b.

Barsanti, K. C. and Pankow, J. F.: Thermodynamics of the formation of atmospheric organic particulate matter by accretion reactions - Part 1: Aldehydes and ketones, Atmos. Environ., 38, 4371-4382, 2004.

Barsanti, K. C. and Pankow, J. F.: Thermodynamics of the formation of atmospheric organic particulate matter by accretion reactions - 2. Dialdehydes, methylglyoxal, and diketones, Atmos. Environ., 39, 6597-6607, 2005.

Barsanti, K. C. and Pankow, J. F.: Thermodynamics of the formation of atmospheric organic particulate matter by accretion reactions - Part 3: Carboxylic and dicarboxylic acids, Atmos. Environ., 40, 6676-6686, 2006.

Bonn, B., Schuster, G., and Moortgat, G. K.: Influence of water vapor on the process of new particle formation during monoterpene ozonolysis, J. Phys. Chem. A, 106, 2869-2881, 2002.

Cai, X. and Griffin, R. J.: Secondary aerosol formation from the oxidation of biogenic hydrocarbons by chlorine atoms, J. Geophys. Res., 111, D14206, doi:14210.11029/12005JD006857, 2006.

Clemitshaw, K. C., Williams, J., Rattigan, O. V., Shallcross, D. E., Law, K. S., and Cox, R. A.: Gas-phase ultraviolet absorption cross-sections and atmospheric lifetimes of several C2-C5 alkyl nitrates, J. Photoch. Photobio. A, 102, 117-126, 1997.

Donahue, N. M., Hartz, K. E. H., Chuong, B., Presto, A. A., Stanier, C. O., Rosenhorn, T., Robinson, A. L., and Pandis, S. N.: Critical factors determining the variation in SOA yields from terpene ozonolysis: A combined experimental and computational study, Faraday Discuss., 130, 295-309, 2005.

Donahue, N. M., Tischuk, J. E., Marquis, B. J., and Huff Hartz, K. E.: Secondary organic aerosol from limona ketone: insights 
into terpene ozonolysis via synthesis of key intermediates, Phys. Chem. Chem. Phys., 9, 2991-2998, 2007.

Feltham, E. J., Almond, M. J., Marston, G., Ly, V. P., and Wiltshire, K. S.: Reactions of alkenes with ozone in the gas phase: a matrixisolation study of secondary ozonides and carbonyl-containing reaction products, Spectrochimica Acta, Part A: Molecular and Biomolecular Spectroscopy, 56A, 2605-2616, 2000.

Finlayson-Pitts, B. J. and Pitts, J. N.: Chemistry of the upper and lower atmosphere: Theory, experiments, and applications, Academic Press, San Diego, 1040 pp., 2000.

Geron, C., Rasmussen, R., Arnts, R. R., and Guenther, A.: A review and synthesis of monoterpene speciation from forests in the United States, Atmos. Environ., 34, 1761-1781, 2000.

Glasius, M., Lahaniati, M., Calogirou, A., Di Bella, D., Jensen, N. R., Hjorth, J., Kotzias, D., and Larsen, B. R.: Carboxylic acids in secondary aerosols from oxidation of cyclic monoterpenes by ozone, Environ. Sci. Technol., 34, 1001-1010, 2000.

Gomez, A., Park, J., Walser, M., Lin, A., and Nizkorodov, S. A.: UV photodissociation spectroscopy of oxidized undecylenic acid films, J. Phys. Chem. A, 110, 3584-3592, 2006.

Griffin, R. J., Cocker III, D. R., Flagan, R. C., and Seinfeld, J. H.: Organic aerosol formation from the oxidation of biogenic hydrocarbons, J. Geophys. Res., 104, 3555-3567, 1999.

Grosjean, D., Williams II, E. L., Grosjean, E., Andino, J. M., and Seinfeld, J. H.: Atmospheric oxidation of biogenic hydrocarbons: reaction of ozone with $\beta$-pinene, D-limonene and transcaryophyllene, Environ. Sci. Technol., 27, 2754-2758, 1993.

Guenther, A., Hewitt, C. N., Erickson, D., Fall, R., Geron, C., Graedel, T., Harley, P., Klinger, L., Lerdau, M., et al.: A global model of natural volatile organic compound emissions, J. Geophys. Res., 100, 8873-8892, 1995.

Guenther, A., Karl, T., Harley, P., Wiedinmyer, C., Palmer, P. I., and Geron, C.: Estimates of global terrestrial isoprene emissions using MEGAN (Model of Emissions of Gases and Aerosols from Nature), Atmos. Chem. Phys., 6, 3181-3210, 2006, http://www.atmos-chem-phys.net/6/3181/2006/.

Guzman, M. I., Colussi, A. J., and Hoffmann, M. R.: Photoinduced oligomerization of aqueous pyruvic acid, J. Phys. Chem. A, 110, 3619-3626, 2006.

Hakola, H., Arey, J., Aschmann, S. M., and Atkinson, R.: Product formation from the gas-phase reactions of $\mathrm{OH}$ radicals and $\mathrm{O}_{3}$ with a series of monoterpenes, J. Atmos. Chem., 18, 75-102, 1994.

Hallquist, M., Waengberg, I., Ljungstroem, E., Barnes, I., and Becker, K.-H.: Aerosol and product yields from $\mathrm{NO}_{3}$ radicalinitiated oxidation of selected monoterpenes, Environ. Sci. Technol., 33, 553-559, 1999.

Harrison, A. G.: Chemical ionization mass spectrometry, 2nd edition, CRC Press, Boc Raton, 208 pp., 1992.

Hartz, K. E. H., Rosenoeron, T., Ferchak, S. R., Raymond, T. M., Bilde, M., Donahue, N. M., and Pandis, S. N.: Cloud condensation nuclei activation of monoterpene and sesquiterpene secondary organic aerosol, J. Geophys. Res., 110, D14208, doi:14210.11029/12004JD005754, 2005.

Hearn, J. D. and Smith, G. D.: Reactions and mass spectra of complex particles using Aerosol CIMS, Int. J. Mass Spectrom., 258, 95-103, 2006.

Heaton, K. J., Dreyfus, M. A., Wang, S., and Johnston, M. V.: Oligomers in the early stage of biogenic secondary organic aerosol formation and growth, Environ. Sci. Technol., 41, 61296136, 2007.

Hewitt, C. N. and Kok, G. L.: Formation and occurrence of organic hydroperoxides in the troposphere: laboratory and field observations, J. Atmos. Chem., 12, 181-194, 1991.

Hoffmann, T., Odum, J. R., Bowman, F., Collins, D., Klockow, D., Flagan, R. C., and Seinfeld, J. H.: Formation of organic aerosols from the oxidation of biogenic hydrocarbons, J. Atmos. Chem., 26, 189-222, 1997.

Iinuma, Y., Mueller, C., Boege, O., Gnauk, T., and Herrmann, H.: The formation of organic sulfate esters in the limonene ozonolysis secondary organic aerosol (SOA) under acidic conditions, Atmos. Environ., 41, 5571-5583, 2007.

Jaoui, M., Corse, E., Kleindienst, T. E., Offenberg, J. H., Lewandowski, M., and Edney, E. O.: Analysis of secondary organic aerosol compounds from the photooxidation of d-limonene in the presence of $\mathrm{NO}_{\mathrm{x}}$ and their detection in ambient $\mathrm{PM}_{2.5}$, Environ. Sci. Technol., 40, 3819-3828, 2006.

Johnson, D. and Marston, G.: The gas-phase ozonolysis of unsaturated volatile organic compounds in the troposphere, Chem. Soc. Rev., 37, 699-716, 2008.

Jonsson, S. M., Hallquist, M., and Ljungstroem, E.: Impact of humidity on the ozone initiated oxidation of limonene, D3-carene, and $\alpha$-pinene, Environ. Sci. Technol., 40, 188-194, 2006.

Karlberg, A. T., Magnusson, K., and Nilsson, U.: Air oxidation of d-limonene (the citrus solvent) creates potent allergens, Contact Dermatitis, 26, 332-340, 1992.

Kleno, J. and Wolkoff, P.: Changes in eye blink frequency as a measure of trigeminal stimulation by exposure to limonene oxidation products, isoprene oxidation products and nitrate radicals, Int. Arch. Occ. Env. Hea., 77, 235-243, 2004.

Koch, S., Winterhalter, R., Uherek, E., Kolloff, A., Neeb, P., and Moortgat, G. K.: Formation of new particles in the gas-phase ozonolysis of monoterpenes, Atmos. Environ., 34, 4031-4042, 2000.

Kroll, J. H., Chan, A. W. H., Ng, N. L., Flagan, R. C., and Seinfeld, J. H.: Reactions of semivolatile organics and their effects on secondary organic aerosol formation, Environ. Sci. Technol., 41, 3545-3550, 2007.

Kroll, J. H. and Seinfeld, J. H.: Chemistry of secondary organic aerosol: Formation and evolution of low-volatility organics in the atmosphere, Atmos. Environ., 42, 3593-3624, 2008.

Leungsakul, S., Jaoui, M., and Kamens, R. M.: Kinetic mechanism for predicting secondary organic aerosol formation from the reaction of d-limonene with ozone, Environ. Sci. Technol., 39, 9583-9594, 2005a.

Leungsakul, S., Jeffries, H. E., and Kamens, R. M.: A kinetic mechanism for predicting secondary aerosol formation from the reactions of d-limonene in the presence of oxides of nitrogen and natural sunlight, Atmos. Environ., 39, 7063-7082, 2005b.

Li, Q., Hu, D., Leungsakul, S., and Kamens, R. M.: Large outdoor chamber experiments and computer simulations: (I) Secondary organic aerosol formation from the oxidation of a mixture of dlimonene and $\alpha$-pinene, Atmos. Environ., 41, 9341-9352, 2007.

Lindinger, W., Hansel, A., and Jordan, A.: Proton-transfer-reaction mass spectrometry (PTR-MS): on-line monitoring of volatile organic compounds at pptv levels, Chem. Soc. Rev., 27, 347-354, 1998.

Mang, S. A., Henricksen, D. K., Bateman, A. P., Andersen, M. P. 
S., Blake, D. R., and Nizkorodov, S. A.: Contribution of carbonyl photochemistry to aging of atmospheric secondary organic aerosol, J. Phys. Chem. A, 112, 8337-8344, 2008.

Nazaroff, W. W. and Weschler, C. J.: Cleaning products and air fresheners: exposure to primary and secondary air pollutants, Atmos. Environ., 38, 2841-2865, 2004.

Ng, N. L., Kroll, J. H., Keywood, M. D., Bahreini, R., Varutbangkul, V., Flagan, R. C., Seinfeld, J. H., Lee, A., and Goldstein, A. H.: Contribution of first- versus second-generation products to secondary organic aerosols formed in the oxidation of biogenic hydrocarbons, Environ. Sci. Technol., 40, 2283-2297, 2006.

Nizkorodov, S. A., Harper, W. W., Blackmon, B. W., and Nesbitt, D. J.: Temperature dependent kinetics of the $\mathrm{OH} / \mathrm{HO}_{2} / \mathrm{O}_{3}$ chain reaction by time-resolved IR laser absorption spectroscopy, J. Phys. Chem. A, 104, 3964-3973, 2000.

Nojgaard, J. K., Christensen, K. B., and Wolkoff, P.: The effect on human eye blink frequency of exposure to limonene oxidation products and methacrolein, Toxicol. Lett., 156, 241-251, 2005.

Norgaard, A. W., Nojgaard, J. K., Larsen, K., Sporring, S., Wilkins, C. K., Clausen, P. A., and Wolkoff, P.: Secondary limonene endo-ozonide: a major product from gas-phase ozonolysis of R(+)-limonene at ambient temperature, Atm. Environ., 40, 34603466, 2006.

Pathak, R. K., Stanier, C. O., Donahue, N. M., and Pandis, S. N.: Ozonolysis of $\alpha$-pinene at atmospherically relevant concentrations: temperature dependence of aerosol mass fractions (yields), J. Geophys. Res., 112, D03201, doi:03210.01029/02006JD007436, 2007.

Presto, A. A., Huff Hartz, K. E., and Donahue, N. M.: Secondary organic aerosol production from terpene ozonolysis. 2. Effect of $\mathrm{NO}_{\mathrm{x}}$ concentration, Environ. Sci. Technol., 39, 7046-7054, 2005.

Presto, A. A. and Donahue, N. M.: Investigation of $\alpha$-pinene + ozone secondary organic aerosol formation at low total aerosol mass, Environ. Sci. Technol., 40, 3536-3543, 2006.

Roberts, J. M., Hahn, C. J., Fehsenfeld, F. C., Warnock, J. M., Albritton, D. L., and Sievers, R. E.: Monoterpene hydrocarbons in the nighttime troposphere, Environ. Sci. Technol., 19, 364369, 1985.

Robinson, A. L., Donahue, N. M., Shrivastava, M. K., Weitkamp, E. A., Sage, A. M., Grieshop, A. P., Lane, T. E., Pierce, J. R., and Pandis, S. N.: Rethinking organic aerosols: semivolatile emissions and photochemical aging, Science, 315, 1259-1262, 2007.

Rohr, A. C., Weschler, C. J., Koutrakis, P., and Spengler, J. D.: Generation and quantification of ultrafine particles through terpene/ozone reaction in a chamber setting, Aerosol Sci. Tech., 37, 65-78, 2003.

Rudich, Y., Donahue, N. M., and Mentel, T. F.: Aging of organic aerosol: bridging the gap between laboratory and field studies, Annu. Rev. Phys. Chem., 58, 321-352, 2007.

Sander, S. P., Friedl, R. R., Golden, D. M., Kurylo, M. J., Moortgat, G. K., Wine, P. H., Ravishankara, A. R., Kolb, C. E., Molina, M. J., Finlayson-Pitts, B. J., Huie, R. E., and Orkin, V. L.: Chemical kinetics and photochemical data for use in stratospheric modeling: evaluation number 15, JPL Publication 06-2 ed., Jet Propulsion Laboratory, Pasadena, California, USA, 2006.

Shilling, J. E., Chen, Q., King, S. M., Rosenoern, T., Kroll, J. H., Worsnop, D. R., McKinney, K. A., and Martin, S. T.: Par- ticle mass yield in secondary organic aerosol formed by the dark ozonolysis of a-pinene, Atmos. Chem. Phys., 8, 2073-2088, 2008 , http://www.atmos-chem-phys.net/8/2073/2008/.

Singer, B. C., Destaillats, H., Hodgson, A. T., and Nazaroff, W. W.: Cleaning products and air fresheners: emissions and resulting concentrations of glycol ethers and terpenoids, Indoor Air, 16, 179-191, 2006.

Spittler, M., Barnes, I., Bejan, I., Brockmann, K. J., Benter, T., and Wirtz, K.: Reactions of $\mathrm{NO}_{3}$ radicals with limonene and $\alpha$ pinene: Product and SOA formation, Atmos. Environ., 40, S116S127, 2006.

Sunil, V. R., Laumbach, R. J., Patel, K. J., Turpin, B. J., Lim, H.J., Kipen, H. M., Laskin, J. D., and Laskin, D. L.: Pulmonary effects of inhaled limonene ozone reaction products in elderly rats, Toxicol. Appl. Pharm., 222, 211-220, 2007.

Talukdar, R. K., Burkholder, J. B., Hunter, M., Gilles, M. K., Roberts, J. M., and Ravishankara, A. R.: Atmospheric fate of several alkyl nitrates. Part 2. UV absorption cross-sections and photodissociation quantum yields, J. Chem. Soc., Faraday Transactions, 93, 2797-2805, 1997.

Tolocka, M. P., Heaton, K. J., Dreyfus, M. A., Wang, S., Zordan, C. A., Saul, T. D., and Johnston, M. V.: Chemistry of particle inception and growth during $\alpha$-pinene ozonolysis, Environ. Sci. Technol., 40, 1843-1848, 2006.

Ungnade, H. E. and Smiley, R. A.: Ultraviolet absorption spectra of nitro paraffins, alkyl nitrates, and alkyl nitrites, J. Org. Chem., 21, 993-996, 1956.

van Reken, T. M., Ng, N. L., Flagan, R. C., and Seinfeld, J. H.: Cloud condensation nucleus activation properties of biogenic secondary organic aerosol, J. Geophys. Res., 110, D07206, doi:07210.01029/02004JD005465, 2005.

Virkkula, A., Van Dingenen, R., Raes, F., and Hjorth, J.: Hygroscopic properties of aerosol formed by oxidation of limonene, $\alpha$ pinene, and $\beta$-pinene, J. Geophys. Res., 104, 3569-3579, 1999.

Wainman, T., Zhang, J., Weschler, C. J., and Lioy, P. J.: Ozone and limonene in indoor air: a source of submicron particle exposure, Environ. Health Persp., 108, 1139-1145, 2000.

Walser, M. L., Park, J., Gomez, A. L., Russell, A. R., and Nizkorodov, S. A.: Photochemical aging of secondary organic aerosol particles generated from the oxidation of d-limonene, J. Phys. Chem. A, 111, 1907-1913, 2007.

Walser, M. L., Desyaterik, Y., Laskin, J., Laskin, A., and Nizkorodov, S. A.: High-resolution mass spectrometric analysis of secondary organic aerosol produced by ozonation of limonene, Phys. Chem. Chem. Phys., 10, 1009-1022, 2008.

Weschler, C. J. and Shields, H. C.: Indoor ozone/terpene reactions as a source of indoor particles, Atmos. Environ., 33, 2301-2312, 1999.

Wilkins, C. K., Wolkoff, P., Clausen, P. A., Hammer, M., and Nielsen, G. D.: Upper airway irritation of terpene/ozone oxidation products (TOPS). Dependence on reaction time, relative humidity and initial ozone concentration, Toxicol. Lett., 143, 109114, 2003.

Winer, A. M., Atkinson, R., and Pitts Jr., J. N.: Gaseous nitrate radical: possible nighttime atmospheric sink for biogenic organic compounds, Science, 224, 156-159, 1984.

Wolkoff, P., Clausen, P. A., Wilkins, C. K., and Nielsen, G. D.: Formation of strong airway irritants in terpene/ozone mixtures, 
Indoor Air, 10, 82-91, 2000.

Wolkoff, P., Clausen, P. A., Larsen, K., Hammer, M., Larsen, S. T., and Nielsen, G. D.: Acute airway effects of ozone-initiated d-limonene chemistry: Importance of gaseous products, Toxicol. Lett., 181, 171-176, 2008.

Yu, Y., Ezell, M. J., Zelenyuk, A., Imre, D., Alexander, L., Ortega, J., D’Anna, B., Harmon, C. W., Johnson, S. N., and FinlaysonPitts, B. J.: Photooxidation of $\alpha$-pinene at high relative humidity in the presence of increasing concentrations of $\mathrm{NO}_{\mathrm{x}}$, Atmos. Environ., 42, 5044-5060, 2008.
Zhang, J., Huff Hartz, K. E., Pandis, S. N., and Donahue, N. M.: Secondary organic aerosol formation from limonene ozonolysis: homogeneous and heterogeneous influences as a function of $\mathrm{NO}_{\mathrm{x}}$, J. Phys. Chem. A, 110, 11053-11063, 2006.

Zhu, L. and Kellis, D.: Temperature dependence of the UV absorption cross sections and photodissociation products of C3-C5 alkyl nitrates, Chem. Phys. Lett., 278, 41-48, 1997. 